\title{
Reasonable Persons, Reasonable Circumstances
}

\author{
CHRISTOPHER JACKSON*
}

\section{TABLE OF CONTENTS}

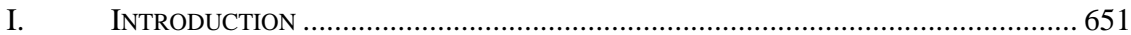

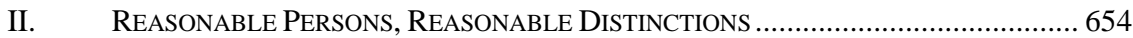

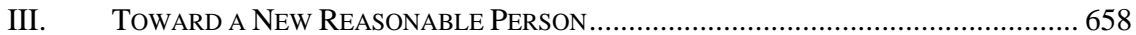

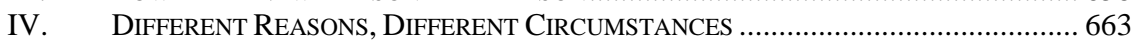

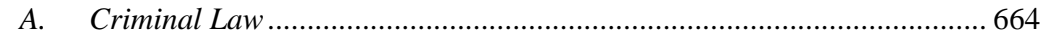

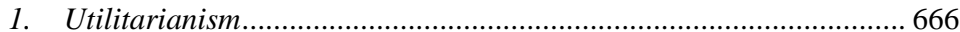

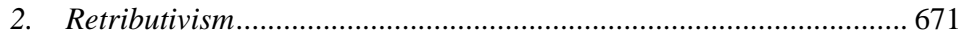

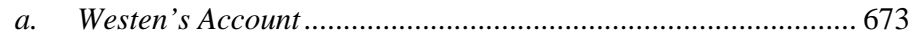

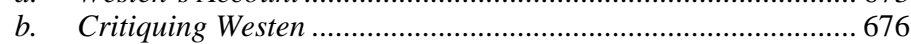

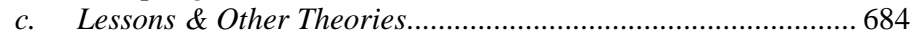

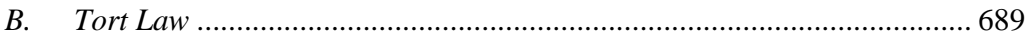

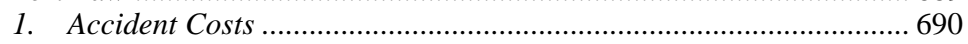

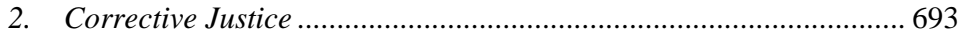

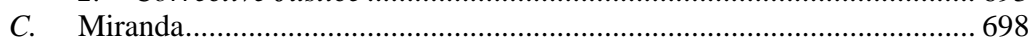

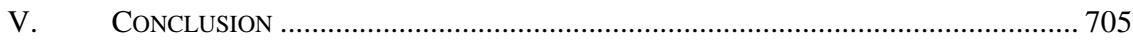

\section{INTRODUCTION}

The reasonable person test, a thread that runs through the fabric of Anglo-American law, has become so common a trope in legal discourse that it scarcely receives much attention in its own right. It is what I previously called a "backdrop" issue of law, a subject that is exceedingly

* (C) 2013 Christopher Jackson. J.D., The University of Michigan Law School (2011); A.B., Princeton University (2007). Thanks to Mike Vitiello, Donald Braman, Caroline Forrell, and Will Thomas for generously agreeing to provide comments. 
common yet infrequently discussed or analyzed on its own terms. ${ }^{1}$ That is not to say, of course, that there is no scholarly commentary on the matter: academics have made strides in investigating what kinds of actions, emotions, or beliefs are reasonable, ${ }^{2}$ the application of the test to a variety of novel cases, ${ }^{3}$ the way in which the reasonable person test negatively impacts the value of equality, ${ }^{4}$ and even, to a limited extent, what the test would look like in a particular area of law. ${ }^{5}$ Still, the test is frequently discussed with little thought about the reasons why it occupies a particular field of law. As Mayo Moran notes in her seminal piece, "[V]irtually no systematic work has been done on the reasonable person." And although approaching the reasonable person test one area of law at a time turns out to make a significant amount of sense, it is worthwhile to step back to get a handle on what the test is and why that approach is probably the right one. This Article analyzes one facet of the test that will yield significant benefits in understanding the subject as a whole: how we should determine which circumstances are part of the reasonable person inquiry. That is, when we apply the reasonable person test and ask what a person would do "given the circumstances," which circumstances are we talking about?

As a disclaimer, this Article does not seek to answer fully even this more narrowly tailored question. The intent is to produce a framework to analyze the issue, one that rejects the traditional framework and replaces it with one that permits us to begin the work necessary to answer the question. On that note, the thesis I defend is this: The circumstances that ought to be part of the test will vary based on one's underlying theoretical

1. Christopher Jackson, Commentary, J.D.B. v. North Carolina and the Reasonable Person, 110 Mich. L. REV. FIRST IMPRESSIONS 9, 9 (2011), http://www.michiganlawreview. org/assets/fi/110/Jackson.pdf.

2. See, e.g., John Gardner, The Mysterious Case of the Reasonable Person, 51 U. TORONTO L.J. 273, 273 (2001).

3. Take for example the application of the reasonable person test to cases of battered spouse syndrome, Holly Maguigan, Battered Women and Self-Defense: Myths and Misconceptions in Current Reform Proposals, 140 U. PA. L. REV. 379 (1991), and to so-called "cultural defenses."

4. The most influential, and best, work is Mayo Moran, Rethinking The ReAsonable Person (2003). But because Moran's solution to the problems posed by the reasonable person test is to replace it with an inquiry into whether the defendant was culpably indifferent, I do not address her final proposal in any detail. Moreover, it is clear that Moran's culpable indifference thesis is meant to apply only to negligencecriminal and civil-rather than all reasonable person tests throughout all areas of law. See id. at 274.

5. For an example in the context of the criminal law, see Peter Westen, Individualizing the Reasonable Person in Criminal Law, 2 CRIM. L. \& PHIL. 137 (2008).

6. Moran, supra note 4, at 2 (emphasis added). Her book, of course, being the major exception. 
commitments. The reasonable person test is in reality a series of tests, albeit ones that share a common core. Which test is used will vary depending not just on the substantive law at issue but also on what underlying theory animates that field. Here, underlying theoretical commitments means one's normative or justificatory view of the given subject matter. A law and economics theorist will offer up a very different account of the justifications of, say, criminal law than a Kantian deontologist, and the differences between the two will generate different versions of the reasonable person test. By unpacking some of these details in several different fields, we will arrive at a better understanding of how the test works in practice.

In undertaking this inquiry, I hope to push against the commonly held belief that it is impossible to articulate a coherent view about which circumstances are relevant in assessing the reasonableness of a defendant's action. Commentators have often despaired that we will never be able to "provide a principled theory by which to distinguish those characteristics with which the law should individualize from those with which it should not."7 Although we cannot distinguish relevant characteristics from irrelevant ones by appealing to any principled a priori method, it is, or at least may be, possible to do so by appealing to our underlying theoretical commitments. Part of the continued frustration with this subject lies in an erroneous assumption that there is a single, globally applicable reasonable person test that works the same way across all different fields of law. Although there is no list of circumstances that are always relevant any time the reasonable person test is applied, it is possible to determine which circumstances must be included within a specific field.

Part II sets out the relevant background, explaining what the reasonable person test is and noting a few important distinctions that properly narrow this Article and focus its subject matter. Part III delves into the heart of the issue, critiquing the commonly used objective/subjective distinction and demonstrating that there is no analytical way to distinguish relevant circumstances from irrelevant ones. Part IV moves on to consider the way the reasonable person test might operate in three different areascriminal law, tort law, and Miranda —and, paying particular attention to

7. Paul H. Robinson, Criminal Law Scholarship: Three Illusions, 2 THEORETICAL INQUIRIES L. 287, 320 (2001); see also MoRAN, supra note 4, at 316 (arguing that the test has become so tortured that the reasonable person "has lived out the last of his days" and ought to be "abolish[ed]"). 
the criminal law, lays out the ways in which the underlying theory of law will have a profound effect on the circumstances that are relevant to the reasonable person.

\section{REASONABLE PERSONS, REASONABLE DistinCtions}

The reasonable person "inhabit[s] every nook and cranny of the common law"; ${ }^{8} \mathrm{he}^{9}$ is a character who has found a place in tort law's negligence, ${ }^{10}$ affirmative defenses in criminal law, ${ }^{11}$ Miranda jurisprudence, ${ }^{12}$ the Establishment Clause, ${ }^{13}$ and even habeas proceedings, ${ }^{14}$ along with a host of others. ${ }^{15}$ And though the reasonable person has existed at least since the famous English tort case Vaughan v. Menlove, ${ }^{16}$ we still have at best only a vague sketch of his biography. The test is most commonly framed by asking what a reasonable person would $\mathrm{do}^{17}$ "under the circumstances." 18 This "objective" standard eschews a purely subjective

8. Gardner, supra note 2, at 273.

9. I use the masculine pronoun in the historical context of the reasonable person because, until quite recently, he was always thought to be a man. See MoRAN, supra note 4, at 199. In all other contexts, I tend toward the feminine.

10. See Mayo Moran, The Reasonable Person: A Conceptual Biography in Comparative Perspective, 14 LEWIS \& CLARK L. REV. 1233, 1238-49 (2010).

11. As Mandiberg notes, on just this limited topic, the reasonable person is used to determine whether a person has a reasonable expectation of privacy, "whether a suspect was actually coerced into confessing, [and] whether a police officer misstated the facts in a search warrant." Susan F. Mandiberg, Reasonable Officers vs. Reasonable Lay Persons in the Supreme Court's Miranda and Fourth Amendment Cases, 14 LEWIS \& ClARK L. REV. 1481, 1485 (2010) (footnote omitted).

12. See id. at 1489-92.

13. Alex Geisinger \& Ivan E. Bodensteiner, An Expressive Jurisprudence of the Establishment Clause, 112 PENN ST. L. REV. 77, 124-25 (2007).

14. In this context, in order to overcome a defense of qualified immunity, the law requires that the allegedly violated right's "contours ... be sufficiently clear that a reasonable official would understand that what he is doing violates that right." Francis v. Giacomelli, 588 F.3d 186, 196 (4th Cir. 2009) (quoting Anderson v. Creighton, 483 U.S. 635, 640 (1987) (internal quotation marks omitted)).

15. See, e.g., Moran, supra note 10 (discussing how the reasonable person is involved in "many different aspects of private law, criminal law, and . . . public law").

16. (1837) 132 Eng. Rep. 490 (C.P.).

17. From here on out, I avoid the more awkward "believe, feel, or do," though the reasonable person test can apply to the defendant's acts, emotions, and beliefs. See Westen, supra note 5, at 138 ("[The reasonable person test] is commonly used to identify the kinds of conduct, mental states, and emotions that wholly or partially exculpate actors from criminal responsibility.” (footnotes omitted)). This roughly tracks Burke's distinction between act reasonableness and emotion reasonableness. See Alafair S. Burke, Equality, Objectivity, and Neutrality, 103 Mich. L. REv. 1043, 1060 (2005).

18. See, e.g., State v. Simon, 646 P.2d 1119, 1120 (Kan. 1982) ("A person is justified in the use of force ... to the extent it appears reasonable to him under the circumstances then existing." (emphasis added)). 
inquiry; rather than asking what the defendant ${ }^{19}$ actually did, it sets out a hypothetical reasonable person and asks, under the circumstances the defendant was faced with, how she would act. It is a way of asking whether the person's conduct was reasonable because "[a] reasonable person is reasonableness rendered incarnate."20

But before we can answer this question, we must first determine which circumstances are relevant to the reasonable person test-which facts about the situation we must saddle the reasonable person with before asking what she would do. The physical features of the situation will likely be included, while the particular peccadilloes of the defendant probably will not, and so on. And although these factors are uncomplicated, a host of others are not so easily sorted. As we shall see in Part IV.A, there is no analytical way to separate relevant circumstances from irrelevant ones: we do not have "a clear sense of which qualities of the reasonable person matter." 21

Before delving into the details, staking out two distinctions will help sharpen our focus. First, there are-at least - two separate questions the reasonable person test poses. In applying the test to a given fact pattern, we might ask how a reasonable person reasons - how she goes about reaching her beliefs or deciding to take some action. This might be rephrased by asking for an account of the term reasonableness, which is, after all, a "measure of ways in which it is right for persons to think, feel or behave." 22 This first question has been explored elsewhere in some detail, ${ }^{23}$ with some disagreement about whether the reasonable person test is meant to instantiate a purely positive notion-asking, roughly, what an average person would do, so that right here means "ordinary"-or a normative one. ${ }^{24}$ On this first question, a number of commentators have

19. The reasonable person test can of course be applied to any party in a given matter. I use the word defendant, rather than the more awkward relevant party or defendant or plaintiff for ease of reading.

20. Westen, supra note 5, at 139.

21. MORAN, supra note 4, at 3; see also Robinson, supra note 7, at 306 (discussing "[w]hich characteristics of a defendant should be attributed to the reasonable person in judging the reasonableness of the defendant's conduct and which characteristics should not”).

22. Westen, supra note 5 , at 138 .

23. E.g., Gardner, supra note 2.

24. Compare Jody D. Armour, Race Ipsa Loquitur: Of Reasonable Racists, Intelligent Bayesians, and Involuntary Negrophobes, 46 STAN. L. REV. 781, 788 (1994) (arguing that there is a normative aspect to the reasonable person test), and Westen, supra note 5, at 138 (referring to the reasonable person test as "a normative measure"), 
fallen in line behind the view that a reasonable person is one "whose actions display appropriate regard for both her interests and the interests of others." 25 But we might also ask what factors should be relevant in making that determination-what context we should give the reasonable person before asking about how she reasons. This Article focuses on the second question, rather than the first. ${ }^{26}$ Now, one might think that the latter question incorporates the former ${ }^{27}$ : if we incorporated all of the characteristics of the defendant into the reasonable person test, we presumably would incorporate all those features of the defendant that lead her to reason the way she reasons. ${ }^{28}$ But we can coherently distinguish between an account of reasonableness and the reasonable person's circumstances: although the defendant's circumstances can effect what conclusions a reasonable person would draw - this is necessarily so, for if they had no such effect, there would be no dispute about whether to include them-that does not answer the question of what the reasonable conclusions are, given a particular set of relevant circumstances. In other words, precisely because we incorporate only some, but not all, of the circumstances of the defendant into the reasonable person test, the reasonable person may arrive at a different conclusion.

with Pinkus v. United States, 436 U.S. 293, 300 (1978) ("The difficulty of framing charges in [the reasonable person] area is well recognized.”), CYNTHIA LEE, MURDER and the Reasonable Man: Passion and Fear in the Criminal Courtroom 235 (2003) (arguing in favor of a shift from a positive to a normative view of the reasonable person), and MORAN, supra note 4, at 13 ("The unsurprising result is that the standard too often operates as an (unjustifiable) standard of ordinariness rather than as a (justifiable) standard of reasonableness.”).

25. ARTHUR RIPSTEIN, EQUALITY, RESPONSIBILITY, AND THE LAW 192 (1999); see also Moran, supra note 4, at 287 ("Let us suppose that indifference to the interests of others is a good general statement of the normative failing that an objective reasonableness standard aims to capture.”). Westen also adopts something quite close to this view, at least in the criminal law context. Westen, supra note 5, at 154 (arguing that the appropriate standard for negligence is asking what a reasonable person would do, assuming that hypothetical person has all of the traits of the actor except that "he fully respected the interests of others that the statute at hand seeks to protect" (internal quotation marks omitted)).

26. Though, as we will see below, this debate has some influence over the question of which circumstances are relevant to the test.

27. At least one commentator has suggested this is so. Moran, supra note 10, at 1240 (" $[\mathrm{T}]$ he case law reveals ... not a uniform norm of reasonableness applied to all but rather a standard that is often, though not inevitably, adjusted to mirror the actual qualities of the litigant in question.”).

28. On this point, an interesting question-one this Article does not address-is whether there is any difference at all between a purely subjective inquiry-asking what the defendant herself believed-and a reasonable person test that incorporates literally every circumstance. In other words, does it make sense to ask what a reasonable person with all of the defendant's particular physical and mental characteristics would believe? Or is that precisely the same as asking what the defendant believed? 
This distinction is important because it is frequently conflated in the literature. Burke, for example, says that "[jurors] see reasonableness in these cases . . . because they share unspoken biases that render male jealousy, heterosexual protectiveness, and white fears of people of color understandable," ${ }^{29}$ which suggests that these biases both are implicitly included as part of the reasonable person's circumstances and that the very cognitive processes of juries are infected with certain undesirable traits. And in Moran's work, Rethinking the Reasonable Person, the author suggests that "[a] uniform norm of reasonableness is not applied to every individual regardless of his or her abilities. Instead, in practice the reasonable person standard often ... borrows heavily from the qualities of the actual litigant." ${ }^{30}$ The phrase "uniform norm of reasonableness" appears to reference an account of what reasonableness is, while "the qualities of the actual litigant" speaks more to the issue of which circumstances are relevant. ${ }^{31}$

The second introductory issue to address concerns an analytical error we should take care to avoid. If we decide that some of the particular characteristics of the defendant do not form part of the reasonable person inquiry, then we are going to have to fill in the reasonable person with something. These are roughly what Moran calls "default characteristics," those that "can be displaced when that characteristic is not possessed by

29. Burke, supra note 17, at 1045 (citing LEE, supra note 24, at 17-45, 67-95, 137-74).

30. MORAN, supra note 4, at 21.

31. It is interesting to note that the inclusion of a factor in the reasonable person test may affect either the balance of reasons a person has for acting or the very way that a person reasons. For example, pleas to include the fact that a defendant is a child in a tort action do not just rely on the fact that children have different reasons for action than adults do, though they do-children derive a benefit from engaging in horseplay that adults do not. See Lisa Belkin, In Praise of Roughhousing, N.Y. Times MotherLodE (June 14, 2011, 3:30 AM), http://parenting.blogs.nytimes.com/2011/06/14/in-praise-ofroughhousing/). It also has something to do with the way that children reason: the level of care I expect from a child is less than I expect from an adult, and this would be true even in cases where I think that if the child were acting perfectly rationally she would do just as the adult does. In other words, it is perfectly reasonable to expect-and to accept - that a child will behave unreasonably. The Supreme Court seems to have recognized and accepted that children reason differently in its recent Miranda opinion. See J.D.B. v. North Carolina, 131 S. Ct. 2394, 2403 (2011) (noting that "[a] child's age is far 'more than a chronological fact”” (quoting Eddings v. Oklahoma, 455 U.S. 104, 115 (1982))). 
the person whose behaviour is being judged[.]"32 The word displaced here demonstrates that there must be some default or baseline to be displaced if we conclude that a circumstance is relevant. As a result, even if we finally determine which circumstances are "irrelevant," we will still implicitly be incorporating particular characteristics about those very circumstances into the test. Consider age: In J.D.B. v. North Carolina, the Supreme Court was asked to decide whether age was a relevant factor in Miranda's in-custody analysis. ${ }^{33}$ The Court found that it was relevant, but had it followed Justice Alito's dissent and concluded that age does not matter, the Court would not actually be ignoring age-it would simply assume that a reasonable person is a reasonable adult. ${ }^{34}$ And because a determination of which circumstances are relevant will fill out, at least in part, what kind of characteristics the reasonable person will always have, we can see that by "relevant" circumstance, I mean something more like "variable" circumstance. Whatever one takes to be the baseline on a given issue-what the reasonable person would look like if we made no allowance for the individual case-calling a circumstance "relevant" just means that it will vary based on what the defendant's actual circumstance was. And so there are now-at least-three issues involving the reasonable person: we must (1) give an account of the term reasonableness; (2) determine which circumstances are relevantwhich parts of the defendant's situation must be incorporated into the test; and (3) for those characteristics we determine irrelevant, decide what characteristics the reasonable person should have.

With these introductory points out of the way, I now turn to the test itself.

\section{TOWARD A NEW REASONABLE PERSON}

In this Part, I argue that the traditional method of distinguishing relevant from irrelevant circumstances - the objective/subjective distinctiondoes not offer any real guidance in parsing the reasonable person test. This argument is a continuation of a previous essay, ${ }^{35}$ which I develop in greater detail and build upon here. The objective/subjective distinction is used throughout both the case law and the academic literature

32. MORAN, supra note 4, at 5. Although here it is not only those characteristics that would be replaced if the defendant had them but also those characteristics that we decide not to replace, even though the defendant does have them.

33. 131 S. Ct. at 2398-99.

34. See id. at 2409 (Alito, J., dissenting). There is nothing analytically wrong with the Court holding that age is not relevant and setting the baseline at a reasonable five-year-old, but no Justice on the Court would seriously entertain such an idea.

35. See Jackson, supra note 1. 
surrounding the reasonable person. ${ }^{36}$ For example, Peter Arenella suggests that "[t]he objective model authorizes criminal liability whenever the individual's conduct has threatened or harmed social interests ... without regard to the actor's subjective culpability."37 Burke recognizes that "[a]n ongoing theme in the scholarly debate ... is the tension between 'objective' and 'subjective' standards." 38 She correctly notes that these terms might refer to several different distinctions. First, by employing a "subjective" test, we might be asking what the defendant herself actually believed; "objective," on the other hand, requires a comparison between the defendant's belief and the beliefs of the hypothetical reasonable person. ${ }^{39}$ The line between the two is easily drawn-any reference whatsoever to a reasonable person necessarily would fall under the label "objective"but the distinction is unhelpful: once we decide to employ an objective test, we must go on to consider which circumstances ought to be included in asking how the reasonable person would act.

Burke expounds a second way of defining the objective/subjective distinction. The terms might be used "to describe whether a jurisdiction considers circumstances that are specific to an individual defendant when applying the universal requirement that the defendant's beliefs be reasonable." 40 "In contrast," she says, “a wholly 'objective' standard of reasonableness compares the defendant's beliefs to those of a hypothetical reasonable person, without taking into account the individual circumstances of the defendant." ${ }^{41}$ But this is nonsensical: how could we ask what a reasonable person would do given the circumstances if we incorporate

36. E.g., Bernard v. Char, 903 P.2d 667, 671-76 (Haw. 1995); Kit Kinports, Criminal Procedure in Perspective, 98 CRIM. L. \& CRIMINOLOGY 71 (2007).

37. Peter Arenella, The Diminished Capacity and Diminished Responsibility Defenses: Two Children of a Doomed Marriage, 77 Colum. L. REv. 827, 831 n.21 (1977). For other examples of discussions of the objective/subjective distinction, see Kevin Jon Heller, Beyond the Reasonable Man? A Sympathetic but Critical Assessment of the Use of Subjective Standards of Reasonableness in Self-Defense and Provocation Cases, 26 AM. J. CRIM. L. 1 (1998); Warren A. Seavey, Negligence-Subjective or Objective?, 41 HARV. L. Rev. 1 (1927); supra Part II. In fact, “dominant” seems to be a more accurate description: there are vanishingly few scholars who conceive of the reasonable person in different terms.

38. Alafair S. Burke, Rational Actors, Self-Defense, and Duress: Making Sense, Not Syndromes, Out of the Battered Woman, 81 N.C. L. REv. 211, 286 (2002).

39. Id. Burke cites a number of cases that use the word subjective in this manner. Id. at 286 n.306.

40. Id. at 287 .

41. Id. 
none of the defendant's circumstances? As Burke notes, “[I]f the defendant stabbed a person who was holding a gun to his head and threatening to pull the trigger, a jury would certainly be permitted to consider the defendant's 'circumstance' of having a loaded gun to his head when determining the reasonableness of his belief ...." 42 Several scholars have unfortunately failed to avoid this confusion. ${ }^{43}$

And so Burke goes on to consider the most prominent way of distinguishing objective circumstances from subjective ones. ${ }^{44}$ These two terms are meant to capture "not the standard of reasonableness, but the types of circumstances that the jury must take into account when assessing reasonableness." ${ }^{25}$ This is generally the same track that Moran considers when she refers to the troubles caused by not having "a clear sense of which qualities of the reasonable person matter normatively and which do not." ${ }^{26}$ Thus, the term objective refers to a subset of circumstances to include in the test, which Burke suggests involves "the size of the defendant, prior threats by the victim ... the victim's movements preceding the incident, and so on." ${ }^{47}$ Subjective factors, on the other hand, refer to things such as the psychological peculiarities of the defendant and should not be incorporated into the test. ${ }^{48}$ Because this third method is the dominant one in the literature, it is worth exploring in some detail.

42. Id. at 290 .

43. Westen, for example, attempts to distinguish between tests that assess a defendant's conduct “only by reference to idealized, impersonal, and disembodied characteristics that make no allowances for an actor's individual traits or foibles" and those that incorporate "some of an actor's individual traits and foibles." Westen, supra note 5, at 139. Robinson likewise makes repeated references to a "purely objective standard,” Robinson, supra note 7, at 301, 302, as does Lee, Cynthia Kwei Yung Lee, Race and Self-Defense: Toward a Normative Conception of Reasonableness, 81 MinN. L. REv. 367, 381, 387 \& nn.53-54 (1996). Even the American Law Institute is liable at least to linguistic slips when it comes to this point: Herbert Wechsler, at the floor debate relating to a section of the Model Penal Code, said, "The standard for judging the adequacy of [common law] provocation is the standard of the ordinary reasonable man. You do not take into account the peculiarities of the actor, whatever they may be." Herbert Wechsler, A.L.I. Floor Debate Relating to Section 210.3, 36 A.L.I. Proc. 125 (1959). Kevin Heller falls into the same trap. See Heller, supra note 37, at 4.

44. This third method is more accurately described as the fourth one that Burke discusses in her work. See Burke, supra note 38, at 290. However, the "true" third option, which attempts to distinguish between the actual circumstances and what the defendant believed were the actual circumstances, is a nonstarter: it does not even purport to address a circumstance that the defendant correctly believes pertains but could not possibly be relevant; for example, the defendant accurately believes that she has a hot temper. See id.

45. Id.

46. MoRAn, supra note 4 , at 3.

47. Burke, supra note 38, at 290-91.

48. See id. at 291. 
Although this version of the objective/subjective dichotomy seems to be promising, it is, at its core, unhelpful. There simply is no principled way to distinguish between objective circumstances and subjective ones. Although at first thought one might classify physical facts such as the defendant's height as objective, a host of others are not so easily sorted. Take, for example, Burke's unsubstantiated claim that "the history of violence between the [assailant] and [the victim]" are straightforwardly objective. $^{49}$ What is it, precisely, that makes the past history of the defendant an objective circumstance? Certainly the Supreme Court would disagree, holding as it did that for Miranda purposes the past interrogation history of the defendant is irrelevant to the reasonable person inquiry. ${ }^{50}$ What makes a fact like the defendant's past experiences so thorny is that it points up the fact that any circumstance can be labeled "objective," in the sense that there is a matter of fact about it. By this I mean that "[t]here is . . . a matter of fact about what kinds of experiences a person had in the past and what effect they have on her reasoning." We could ensure that a test incorporating any given feature $X$ of a person is objective by asking what a reasonable person with $X$ would do under the circumstances. So, for example, we could take a supposedly subjective fact such as the defendant's bad temper and simply ask what a reasonable person with a bad temper would do under the circumstances. This interpretive move would preserve the objectivity of the reasonable person test, but it includes a factor most would intuitively classify as subjective. And so the term objective does not have any explanatory power.

Turning to the second half of the dichotomy, perhaps the word subjective provides some guidance. At first one might think that subjective refers to the psychological facts about the defendant. Thus, Burke may be on firmer ground when she asserts that "[j]urors should not, for example, consider the evidence from the perspective of a 'reasonable delusional paranoid schizophrenic' or 'reasonable sociopath."”52 But although

49. Id. at 292.

50. Yarborough v. Alvarado, 541 U.S. 652, 668-69 (2004). Although given that Yarborough involved a different area of law, it is possible the Supreme Court would reconsider its position in the criminal law context.

51. Jackson, supra note 1 , at 11.

52. Burke, supra note 38, at 293. Although it is not so clear, this really is much firmer ground. There is significant philosophical dispute about whether physical and psychological facts really are differences in kind, rather than degree. A great deal of philosophical literature is devoted to the question of whether the various sciences are reducible to physics or are instead irreducible separate fields of study. See, e.g., Jaegwon 
omitting the psychological facts from the reasonable person test sounds simple enough, there are a number of factors readily characterized as psychological that we would still want to import into the test. Consider a person's language ability. If it must be put under the heading of either "psychological" or "nonpsychological"—and, logically speaking, it mustit best fits into the former category: it does not "keep good company with physical descriptors like height, weight, and eye color."53 But a court could not seriously rule out a defendant's language ability in employing the reasonable person test. For Miranda purposes, a defendant is "in custody" if a reasonable person in her circumstances would not feel free to leave. ${ }^{54}$ Consider a situation where a person is being questioned by the police; in the first iteration, she speaks Italian, but not English, and in the second, she speaks English, but not Italian. If the police were to say, "You are under arrest and you are not permitted to leave" in English, an Italianspeaking defendant could not argue that she was in custody because a reasonable English-speaking person would not have felt free to leave. And similarly, if the police made the same statement in Italian, an English-speaking individual could not seriously assert that because a reasonable Italian-speaking person would not have felt free to leave, she should have been read her Miranda rights. Whether the suspect is in custody will turn on whether she is able to understand what the police officers are saying, and so the defendant's language ability simply must be taken into account. For the same reason, any appeal to "external” and "internal" circumstances ${ }^{55}$ is similarly unavailing: features such as language ability and even blindness would be improperly screened out. ${ }^{56}$

All of this suggests that there is no analytical way to determine which characteristics are relevant and which are not. True, I am asserting a negative, but this Article has probed the most commonly-indeed, nearly universally-used method and demonstrated that it offers little in the way of guidance. Moreover, as Moran has pointed out, the case law suffers from significant cognitive dissonance in the way it reasons about including or excluding factors. ${ }^{57}$ She notes, for example, that intelligence

Kim, Multiple Realization and the Metaphysics of Reduction, 52 PHIL. \& PHENOMENOLOGICAL RES. 1 (1992).

53. Jackson, supra note 1 , at 11 .

54. Yarborough, 541 U.S. at 663 (quoting Thompson v. Keohane, 516 U.S. 99, 112 (1995)).

55. This is the distinction Justice Alito adopts in J.D.B. v. North Carolina, $131 \mathrm{~S}$. Ct. 2394, 2411-12 (2011) (Alito, J., dissenting).

56. Jackson, supra note 1 , at 12 . Westen might implicitly be appealing to this kind of distinction; for more on that score, see infra Part IV.A.2.a.

57. Moran points out several of these inconsistencies in Rethinking the Reasonable Person. Moran, supra note 4, at 5-6. 
is treated differently for children and adults and that physical disabilities are treated differently from mental ones. ${ }^{58}$ Taken together, these arguments shift the burden of persuasion on to one who would dispute this claim.

Given this conclusion, one might think it would be best to "imagine [relevant circumstances] as a spectrum," 59 with some features clearly in, some clearly out, and a great many falling somewhere in between. The Model Penal Code (MPC) certainly takes this position. In defining criminal negligence, the code says that "the actor's failure to perceive [the risk] . . . involves a gross deviation from the standard of care that a reasonable person would observe in the actor's situation."60 Although the MPC does note that the actor's intelligence, heredity, and temperament are not relevant, ${ }^{61}$ it did not attempt to draw a clearer line between relevant and irrelevant circumstances, saying, "There thus will be room for interpretation of the word 'situation,' and that is precisely the flexibility desired.",62 However, we should not give up so easily by throwing everything to the jury. Although it may be impossible to arrive at a perfect answer, surely we can provide greater guidance as to which circumstances are relevant than simply declaring that reasonable minds differ. It is to this project that I now turn.

\section{DIFFERENT REASONS, DIFFERENT CIRCUMSTANCES}

Having discussed the pitfalls of the traditional method used to sort relevant and irrelevant circumstances, I now turn to consider some alternatives. As Moran suggests in the context of the criminal law,

58. For example, she notes that "Vaughan $v$. Menlove seem[s] to respond with an emphatic 'yes"' to the question of whether a defendant is held to the same level of intelligence as the reasonable person, but "courts reject this approach in the [case of] children.” Id. at 5, 6. But as Part IV.A will make clear, Moran is implicitly relying on what is known as "the control principle" in arguing that these distinctions are examples of cognitive dissonance.

59. Moran, supra note 10, at 1272.

60. MODEL Penal CODE § 2.02(2)(d) (1985) [hereinafter MPC].

61. Id. $\S 2.02 \mathrm{cmt}$. at 242 .

62. MPC $\S 210.3 \mathrm{cmt}$. at 63 (1980). Though it is not clear, this is the best route to take. Among several other reasons, recent scholarship has found evidence suggesting that there is significant inconsistency in the way that people draw the line and that the way a given individual comes out in a particular case is correlated with her political beliefs. See, e.g., Dan M. Kahan \& Donald Braman, The Self-Defensive Cognition of Self-Defense, 45 AM. CRIM. L. REV. 1 (2008). 
I think we can distinguish between the culpability-determining functions of the reasonable person .... and the judgment-related function where the reasonable person is employed [for a different purpose]. And these different functions have, I would suggest, very different implications for the understanding of the subjective and objective components of the standard. 63

Moran's intuition is roughly correct: the reasonable person test has different functions in different contexts, and as such, the circumstances that are relevant to the test will vary. However, as this Article argues below, Moran does not quite go far enough: the circumstances of the reasonable person test will vary, but they will vary depending not on just the area of law in which it is employed but also on the underlying theory that animates a given area of law. ${ }^{64}$ To develop this contention, I consider three areas of law: criminal law, tort law, and the Supreme Court's Miranda jurisprudence.

\section{A. Criminal Law}

As George Fletcher has noted, "One of the most striking particularities of our discourse is its pervasive reliance on the term 'reasonable.' ... In criminal law, we talk incessantly of reasonable provocation, reasonable mistake, reasonable force, and reasonable risk." 65 The MPC's definitions of the various levels of mens rea are perhaps the most obvious examples. The MPC states that

[a] person acts negligently ... when he should be aware of a substantial and unjustifiable risk .... [T] [he actor's failure to perceive [the risk], considering the nature and purpose of his conduct and the circumstances known to him, involves a gross deviation from the standard of care that a reasonable person would observe in the actor's situation. ${ }^{66}$

Similarly, the MPC defines recklessly as when a person acts with conscious disregard of a substantial and justifiable risk and says that the "risk must be of such a nature and degree that, considering the nature and purpose of the actor's conduct and the circumstances known to him, its disregard involves a gross deviation from the standard of conduct that a law-abiding

63. Moran, supra note 10 , at 1272 . Though never fully articulated, Lee suggests something similar when she notes that an objective standard "views social harm ... a the linchpin of criminal liability" while "[a] subjective model, in contrast, views culpability as the central defining feature of criminal liability.” Lee, supra note 43, at 381.

64. This Article does not mean to rule out the possibility that there are further subdivisions to be made: perhaps there is not a reasonable person test just for the criminal law but rather one test for reasonable force cases and another for reasonable mistake ones.

65. George P. Fletcher, The Right and the Reasonable, 98 HARV. L. REV. 949, 949 (1985).

66. MPC § 2.02(2)(d) (1985). 
person would observe in the actor's situation." ${ }^{\text {,67 }}$ In a similar vein, the Supreme Judicial Court of Massachusetts held that the standard of "wanton or reckless conduct" is satisfied if the defendant "[k]now[s] facts that would cause a reasonable man to know the danger."68 The MPC permits "the use of force upon or toward another person" so long as "the actor believes that such force is immediately necessary for the purpose of protecting himself." 69 But section 3.09 limits the availability of this defense in cases where "the actor is reckless or negligent in having such belief or in acquiring or failing to acquire any knowledge or belief that is material to the justifiability of his use of force., ${ }^{, 70}$ There are of course other examples. ${ }^{71}$

Traditionally, there have been two separate justifications for imposing criminal sanctions ${ }^{72}$ : retributivism and utilitarianism. ${ }^{73}$ John Rawls has

67. Id. § 2.02(2)(c).

68. Commonwealth v. Welansky, 55 N.E.2d 902, 910 (Mass. 1944).

69. MPC § 3.04(1). The high profile case involving the killing of Trayvon Martin provides another example. There the defendant, George Zimmerman, claimed selfdefense. At the close of the evidence, the judge instructed the jury, "In deciding whether George Zimmerman was justified in the use of deadly force, you must judge him by the circumstances by which he was surrounded at the time the force was used." Ta-Nehisi Coates, Trayvon Martin and the Irony of American Justice, AtLANTIC (July 15, 2013, 5:09 AM) (citing George Zimmerman Trial: Final Jury Instructions, SCRIBD, http://www.scribd. com/doc/153354467/George-Zimmerman-Trial-Final-Jury-Instructions (last visited Nov. 24, 2013)), http://www.theatlantic.com/national/archive/2013/07/trayvon-martin-and-the-iron y-of-american-justice/277782/.

70. MPC § 3.09(2). The test thus shows up in two places in this provision: in determining whether a particular belief was reckless or negligent and whether a fact is material. See id. Interestingly enough, the MPC defines negligence and recklessness with the phrase "considering the nature and purpose of the actor's conduct and the circumstances known to him," which goes some way in filling out which circumstances are relevant. See id. § 2.02(2)(c).

71. See, e.g., id. § 210.3(1)(b) (voluntary manslaughter); id. § 3.05 (defense of others); Neder v. United States, 527 U.S. 1, 25 (1999) (materiality in the context of mail fraud); State v. Williams, 653 A.2d 902, 905 (Me. 1995) (foreseeability in the context of accomplice liability); Girouard v. State, 583 A.2d 718, 722 (Md. 1991) (adequate provocation); Ex parte Fraley, 111 P. 662, 663 (Okla. Crim. App. 1910) (character of victim related to self-defense); State v. Shumway, 2002 UT 124, ๆ 9, 63 P.3d 94 (extreme emotional disturbance).

72. But there are others-most notably the republican theory put forward by John Braithwaite and Philip Pettit in John Braithwaite \& Philip Pettit, Not Just Deserts: A REPUBLICAN THEORY OF CRIMINAL JUSTICE (1990).

73. Michael S. MoOre, LAW and Psychiatry: Rethinking the Relationship 237 (1984) ("[T] a net social gain (utilitarian) and giving just deserts (retributivist) ....”). Moore goes on to consider a "mixed theory" of punishment, $i d$., which is discussed in greater detail below. See infra notes 109-11 and accompanying text. 
explained that the retributivist view "is that punishment is justified on the grounds that wrongdoing merits punishment. It is morally fitting that a person who does wrong should suffer in proportion to his wrongdoing." ${ }^{74}$ Utilitarianism, in contrast, "holds that on the principle that bygones are bygones and that only future consequences are material to present decisions, punishment is justifiable only by reference to the probable consequences of maintaining it as one of the devices of the social order., ${ }^{, 75}$ This Article will consider these two competing theories. ${ }^{76}$

\section{Utilitarianism}

Today's criminal justice system is substantially influenced by "utilitarian reformers of the late eighteenth century and the early nineteenth century."77 Beginning with Italian reformer Cesare Beccaria, reformers advocated for a system of punishment that was "moderate but regular, certain, swift, and proportioned to the threat the offense posed to society."78 Jeremy Bentham, probably the best known proponent of a utilitarian approach to criminal law, systematized the movement that had been building for decades in his seminal work Introduction to the Principles of Morals and Legislation in $1789 .^{79}$ Bentham called for a limiting condition on punishment: "The cases in which punishment ought not to be inflicted" include "those punishments inefficacious which have no power to produce an effect upon the will, and which, in consequence, have no tendency towards the prevention of like acts." 80 This concern has been distilled into what criminologists today recognize as the three utilitarian justifications for punishment: specific deterrence, general deterrence, and incapacitation. ${ }^{81}$

74. John Rawls, Two Concepts of Rules, 64 PHIL. REv. 3, 4-5 (1955).

75. Id. at 5 .

76. It is true that these two theories are technically justifications for punishment, not for criminal law as an institution. This Article therefore makes the assumption that the substantive content of the criminal law should track the proper justification for punishment: that under a utilitarian framework, the law should criminalize conduct that if punished would lead to a better state of affairs and that under a retributivist framework, the law should criminalize conduct that is deserving of punishment. With respect to utilitarianism, one might instead adopt a more limited view, holding that utilitarianism justifies the imposition of criminal punishment but does not justify or explain the substantive criminal law. This Article discusses the possibility of this more limited utilitarian view directly.

77. JOHN KAPLAN ET AL., CRIMINAL LAW: CASES AND MATERIALS 31 (6th ed. 2008).

78. Id.

79. Id. at 31-32.

80. Jeremy Bentham, The Theory of Legislation 322 (C.K. Ogden ed., Richard Hildreth trans., Morrison \& Gibb Ltd. 1931) (1802).

81. See e.g., Kevin M. Carlsmith et al., Why Do We Punish? Deterrence and Just Deserts as Motives for Punishment, 83 J. Personality \& Soc. Psychol. 284, 285-86 
The theory has gained significant traction since Beccaria and Bentham; indeed, the nineteenth century "witness[ed] the proliferation of penitentiaries and criminal codes [reformers] had called for." ${ }^{22}$ Up until the late twentieth century, "a descendant of utilitarianism dominated criminal justice policy-making." ${ }^{\text {"3 }}$ Thus, many fell in line behind the view that the law should "assign[] punishment levels to each individual in a fashion calculated to minimize the total social cost of crime and crime prevention.",84

There are competing interpretations of utilitarianism. The version espoused and defended by the likes of Bentham, John Stuart Mill, and Henry Sidgwick—commonly known as "classical utilitarianism”- holds "that we should always do what will maximize pleasure, or happiness, and minimize pain, or unhappiness. ${ }^{85}$ In contrast, so-called "preference utilitarianism" holds that "we should do what, on balance, furthers the preferences of those affected." 86 To keep this project manageable, this Article limits its discussion to preference utilitarianism, most notably advanced by Peter Singer. ${ }^{87}$

If we buy into preference utilitarianism, the criminal justice system ought to do precisely that-maximize preference satisfaction. ${ }^{88}$ The application of the reasonable person test, then, is rather simple on the first run-through. In determining whether a particular factor should be relevant to the test, we must ask whether the inclusion of that factor would satisfy a larger number of preferences. So, for example, in determining whether one can claim that she was not criminally negligent because of her age, that will depend on whether the inclusion of age as a factor in the reasonable person test will lead to a larger number of preferences being satisfied. But as with any application of utilitarianism to a real-

(2002); Mark C. Stafford \& Mark Warr, A Reconceptualization of General and Specific Deterrence, 30 J. RES. CRIME \& DELINQ. 357 (1993).

82. KAPLAN ET AL., supra note 77, at 32.

83. BRAITHWAITE \& PETTIT, supra note 72, at 2.

84. Louis Michael Seidman, Soldiers, Martyrs, and Criminals: Utilitarian Theory and the Problem of Crime Control, 94 YALE L.J. 315, 315-18 (1984).

85. Peter Singer, Practical Ethics 13 (3d ed. 2011).

86. Id. (emphasis added).

87. E.g., Peter Singer, Animal Liberation 5 (Harper Perennial 2009); Singer, supra note 85 , at 13 .

88. Though some theoretical work would still have to be done filling out what count as "preferences." For a related discussion, see infra pp. 690-93 (discussion of the definition of costs in the law and economics context). 
world scenario, complications inevitably arise. Adopting a utilitarian view of the criminal law turns the questions involved in applying the reasonable person test from the normative into the empirical. This is hardly something a utilitarian would take pains to quibble with, but it is worth noting. A more traditional approach to criminal law might consider normative questions: whether it is just to sanction an individual in a particular case, whether the state ought to use its coercive power to prevent this kind of conduct, and so on. But a utilitarian approaches the matter much differently: questions in criminal law will not turn on the arguments expounded by philosophers and political theorists but on the data collected by social scientists. ${ }^{89}$

Moreover, utilitarianism assumes that it would be possible to reach a definitive answer to these empirical questions. But as Don Herzog once noted, "As far as I know, no one has ever attempted even a sketch of [the decision utilitarianism demands] for any actual problem.... For good reason, too: we would need to know unfathomably more about consequences and individuals than we do or can know." 90 For example, in trying to determine whether a particular factor is relevant in assessing a self-defense claim, the quick-and-dirty analysis is whether taking into account that factor would reduce the number of killings. But this is woefully incomplete because there are an "unfathomable" number of other effects besides the raw number of killings radiating out of the decision to include or exclude a particular factor that would affect preference satisfaction, and it would be difficult indeed to map perfectly all of those ripple effects.

Adopting a utilitarian approach to criminal law might also require us to reject our intuitions about the reasonable person test. We might wonder whether the factors relevant to the test should stay constant across different defendants or if instead we should decide the issue on a caseby-case basis and say, for example, that Defendant \#1's past history of abuse is relevant in determining whether she can make out a self-defense claim but Defendant \#2's past history of abuse cannot be considered though she makes precisely the same argument. ${ }^{91}$ Or perhaps it turns out

89. For a more detailed discussion of some of the empirical questions involved in adopting a utilitarian approach to criminal law, see infra notes 99-102.

90. Don Herzog, Without Foundations: Justification in Political Theory 131 (1985).

91. This can be aptly analogized to the distinction between act utilitarianism, which holds that one ought to do the action that maximizes utility, and rule utilitarianism, which holds that one ought to act in conformity with the rule that maximizes utility. In both cases the distinction is illusory: both theories are grounded in the justification that they will maximize utility. But it is an empirical question which theory best maximizes utility, and a utilitarian would be obligated to follow whichever one does so. For an 
that in self-defense cases, utility is maximized only when we refuse to consider the physical strength of the defendant or the fact that the victim was armed with a deadly weapon. For these reasons, it is not possible to say much of anything about what the reasonable person test should look like under a utilitarian view: because the question is entirely dependent on empirical questions, every facet of the test is open to revision. The most we can say is that the question as to whether a particular factor is relevant to the test will turn on whether the inclusion of the factor will maximize utility. ${ }^{92}$ Any suggestion beyond this simple proposition is open to empirical criticism.

Of course, as noted above, utilitarianism is not just a theory of criminal law-it is a general one of normative ethics. ${ }^{93}$ But most utilitarian justifications for punishment are more narrowly tailored. Rather than taking a full-on utilitarian approach where the maximization of utility is a maxim to be applied across all contexts, many utilitarian criminologists cabin their weighing of costs and benefits to the criminal law only. ${ }^{94}$ Criminal law, the argument goes, ought only to be concerned with the reduction of crime. ${ }^{95}$ In the field of tort law, Scott Hershovitz notes that economists ignore tort's collateral costs and benefits "to keep their models of tort tractable" 96 : it would be impossible to create a model that perfectly captures each and every causal effect tort law has, but there is

extended discussion of this issue, see DAVID LyONS, FORMS AND LIMITS OF UTILITARIANISM 62-118 (1965); J. J. C. SMART \& BERNARD WiLLIAMS, UtilitARIANISM: FOR AND AGAinST 3, 9-12 (1973).

This issue is just one of the many ways in which critiques are leveled against utilitarianism on grounds that it requires us to give up some of our most basic intuitions. See, e.g., H. J. McCloskey, A Non-Utilitarian Approach to Punishment, 8 INQUIRY 249, 253-54 (1965). In the context of the criminal law, it is frequently noted that utilitarianism might justify framing the innocent, inflicting excessive punishment, adopting illegitimate trial procedures, and criminalizing noncriminal behavior such as one's political affiliations. E.g., id.

92. And even that statement is subject to revision if it turns out that the application of the reasonable person test in the criminal law brings about less utility than, say, a purely subjective test. Or perhaps utilitarianism demands that the criminal law be abolished altogether. For a more in-depth discussion on this last point, see Gilbert M. Cantor, An End to Crime and Punishment, SHINGLE, May 1976, at 1.

93. See, e.g., SINGER, supra note 85, at 10-11.

94. See e.g., Scott Hershovitz, Harry Potter and the Trouble with Tort Theory, 63 STAN. L. REV. 67, 85 (2010).

95. Thus, the reason why a person is interested in the reduction of crime might be on nonutilitarian grounds.

96. Hershovitz, supra note 94 , at 85. 
still some value in creating the more narrowly tailored model focusing only on accident costs, "even though our epistemic limitations entail that any conclusions we reach will be qualified and tentative."97 Similarly, it might be better to narrow the scope of our utilitarian approach to criminal law and take it as given that we should "manipulate punishment and enforcement levels so as to reduce the social cost of crime and crime prevention to some theoretical minimum."

This line of thinking finds support in the way utilitarian criminologists approach the criminal law. As James Q. Wilson noted, in applying a utilitarian rationale to punishment, we must grapple with a variety of empirical factors about the way that human beings respond to rewards and punishments including whether people are "incapable of assessing the risks" of their actions in the first place and whether and to what extent "would-be offenders are reasonably rational and respond [rationally] to their perception of the costs and benefits attached to alternative courses of action." 99 Scholars have debated whether increasing the severity, rather than the probability, of punishment has any deterrent effect. ${ }^{100}$ Similarly, some criminologists have argued that the deterrent effects of crime are "front-loaded," so that the "initial humiliation and stigma ... comes at the beginning of the term and is not increased by adding additional years [to the sentence]." ${ }^{101}$ Dan M. Kahan has noted that empirical studies on the reasons why people obey the law "reveal a strong correlation between a person's obedience and her perception of others' behavior and attitudes toward the law" and a correspondingly weak correlation between obedience and the threat of punishment. ${ }^{102}$ In each of these discussions, the implicit assumption is that the purpose of the criminal law is not simply to maximize utility but to efficiently reduce the costs associated with criminal activity. Perhaps this approach will get more traction in determining which circumstances are relevant to the reasonable person test.

Unfortunately, that is not the case: the adoption of utilitarianism in this narrow sense does not tell us anything about the factors relevant to the reasonable person inquiry. In many cases the reasonable person test is

97. Id. at 86.

98. See Seidman, supra note 84 , at 317 n.7.

99. JAMEs Q. WiLson, Thinking About Crime 117-21 (rev. ed. 1983).

100. See Anthony N. Doob \& Cheryl Marie Webster, Sentence Severity and Crime: Accepting the Null Hypothesis, 30 CRIME \& JusT. 143, 181-89 (2003) (conducting a literature review on the subject and concluding that "[w]e could find no conclusive evidence that supports the hypothesis that harsher sentences reduce crime through the mechanism of general deterrence").

101. Seidman, supra note 84, at 331.

102. Dan M. Kahan, Social Influence, Social Meaning, and Deterrence, 83 VA. L. REv. 349, 354 (1997). 
used to determine whether a particular action is criminal. Fact finders apply the reasonable person test in crimes involving recklessness and negligence to determine whether the defendant has committed a criminal act, ${ }^{103}$ in self-defense cases to tell us whether the defendant's actions are excused, ${ }^{104}$ and so on. But if we are operating under a framework that seeks to reduce crime, we must first decide what kind of conduct we are going to label "criminal." It makes little sense to talk about crime reduction when the issue depends on whether the conduct is prohibited in the first place-we have begged the question. Although the point being made here is relatively narrow, it has a much broader application and can be easily overlooked. Utilitarian justifications for criminal punishment are covertly dependent on having a robust sense of what ought to be prohibited. That robust sense must come from either a broader commitment to utilitarianism-discussed above — or some other, nonutilitarian theory. ${ }^{105}$

Whether one takes issue with my conclusions on utilitarianism as applied to the criminal law, I have at least laid out the framework that a utilitarian would seek to apply in making doctrinal decisions involving the reasonable person test: we should decide to include or exclude factors based on whether they maximize "utility," however one defines that term-whether in terms of preference satisfaction generally, the social costs of crime, or something else altogether.

Having surveyed how utilitarian approaches to criminal law would approach the reasonable person test, I now turn to consider what a blamed-based account of criminal law has to say on the matter.

\section{Retributivism}

Retributivism is most often associated with the German philosopher Immanuel Kant, who famously argued,

Juridicial Punishment can never be administered merely as a means for promoting another Good ... but must in all cases be imposed only because the individual on whom it is inflicted has committed a Crime.... [W]oe to him

103. See supra note 66 and accompanying text.

104. See supra note 69 and accompanying text.

105. A utilitarian in this second sense might adopt a blame-based view of the criminal law, as this Article discusses in Part IV.A.2, to fill in this gap. 
who creeps through the serpent-windings of Utilitarianism to discover some advantage that may discharge him from the Justice of Punishment . . . 106

On this view it is a moral good to punish the blameworthy, apart from any consequences that might result. Until the 1970s, very few legal scholars took a retributive approach to criminal law. ${ }^{107}$ But beginning at that time, retributivism underwent a renaissance of sorts. ${ }^{108}$

It is worth noting that the so-called "mixed theory" of punishmentdiscussed briefly above-would fit under the retributivist label for this Article's purposes. Under a mixed theory, two conditions are necessary for the justification of punishment: "[T] $]$ he person on whom [punishment] is imposed is found to have committed an offense under circumstances that permit his conduct to be characterized as blameworthy," and the punishment must be "designed to prevent the commission of offenses."109 Moral blame, in other words, is a "limiting principle," 110 and therefore the mixed-bag theorist will have to take retributivist concerns fully into account. ${ }^{111}$

As mentioned, the retributivist holds that the criminal law may only punish the blameworthy. Therefore, the question of what factors are relevant in the reasonable person test will turn on whether the inclusion or exclusion of a given factor will more accurately capture when a person is to blame. To determine what factors are relevant, then, we must first know what it is that makes a person blameworthy and thus subject to punishment. To make our discussion manageable, this Article will limit itself to one promising candidate: Peter Westen's theory that a person is to blame for failing to "manifest[] appropriate ex ante concern on his part for" certain interests. ${ }^{112}$ I focus on Westen's theory primarily because, as we shall see, his interpretation of blame garners significant support across a wide

106. ImManuel Kant, The Philosophy of LaW 195 (W. Hastie trans., Scribner \& Welford 1887) (1796-1797).

107. BRAithWAite \& PetTit, supra note 72, at 2.

108. Id. at $2-5$.

109. Herbert L. Packer, The Limits of the Criminal Sanction 62 (1968).

110. Id. at 66; see also Alan H. Goldman, The Paradox of Punishment, 9 PHIL. \& PuB. AfF. 42, 48 (1979) ("[The mixed theory of punishment] views the social goal of punishment as deterrence, and yet recognizes that we are entitled to pursue this goal only when we restrict deprivation of rights to those forfeited through crime or wrongdoing.”).

111. There is one way in which the mixed-bag theory and retributivism come apart. If the inclusion or exclusion of a particular factor to the reasonable person test (1) would not lead to the punishing of the morally blameless and (2) would prevent the commission of offenses, then a mixed-bag theorist would have reason to include or exclude that factor while a retributivist would have no reason to either way. Because this would be a highly unusual circumstance, this Article cabins the issue off for purposes of this discussion.

112. Westen, supra note 5, at 142-43. 
variety of academics due to its implicit reliance on what is known as the "control principle" - the idea that a person can be to blame only for that which she could control. ${ }^{113}$

\section{a. Westen's Account}

Westen begins by distinguishing two types of reasonableness-a distinction that he argues is frequently overlooked in the literature. As a "tentative distinction," Westen notes that there is a difference between the claim that one did not engage in unlawful conduct and the claim that one is not culpable. ${ }^{114}$ Westen articulates the difference in terms of actus reus and mens rea, although he does not use those terms, ${ }^{115}$ but it is probably better understood as the difference between obligation and blame: the question of what I am obligated to do is not the same as asking what I am to blame for. Westen notes that this distinction is significant "because, although reasonableness often exculpates in each respect, the traits that are selected to constitute a reasonable person vary accordingly."116 In other words, fact finders will apply the reasonable person test differently to determine what kind of conduct is prohibited than when determining

113. For a discussion of academics that also rely on the control principle in the context of the reasonable person test, see infra text accompanying note 160. Compare Letter from Oliver Wendell Holmes, Jr. to Harold J. Laski (Dec. 17, 1925), in 1 HolmesLASKI LETTERS 806 (Mark DeWolfe Howe ed., 1953) ("If I were having a philosophical talk with a man [about to be executed] I should say, I don't doubt that your act was inevitable for you but to make it more avoidable by others we propose to sacrifice you to the common good. You may regard yourself as a soldier dying for your country if you like. But the law must keep its promises.”).

114. Westen, supra note 5, at 140-41.

115. See id. at 141 (referring to "lack of unlawful conduct" and "lack of culpability"). Westen argues that lack of culpability is a case where "despite bringing about the specified state of affairs that a statute explicitly seeks to prevent, [a person] nevertheless lacks the accompanying culpability that the statute requires.” Id. But the mens rea requirement is an element of a given offense and is a part of that which the statute "explicitly seeks to prevent," making this an odd way to phrase the distinction. Westen tries to avoid this difficulty by implying that a statute is keyed toward preventing a particular state of affairs, but this fails to recognize (a) mens rea is a necessary condition for criminal liability and (b) not all criminal statutes are phrased in terms of states of affairs. The MPC, for example, explicitly distinguishes elements that relate to nature of the conduct, attendant circumstances, and result of conduct. E.g., MPC $\S 2.02(2)$ (1985) (laying out the definition of various levels of mens rea and how they apply to each of those three categories).

116. Westen, supra note 5, at 141 . 
whether a particular defendant is blameworthy. ${ }^{117}$ "[W] functions as a standard of conduct, it operates as a measure of the lawfulness of end-states of affairs .... And, as such, its personification, the 'reasonable person,' rightly consists of idealized characteristics that make no allowances for an actor's individual traits or foibles."118 This kind of reasonableness - "Reasonableness-1," in his parlance_-can be determined without any reference to the particular characteristics of the defendant. ${ }^{119}$ When we ask, for example as the MPC does, whether the risk the actor consciously disregarded was "substantial" and "unjustifiable," we need not impart any fact about the actor herself; questions regarding the degree of the risk "are entirely a function of which risks the people of the state regard as acceptable and unacceptable-not a function of contrary or dissenting perceptions, emotions or judgments by individual actors." 120

In contrast, when the reasonable person test is used to determine whether an agent is culpable, we must employ "Reasonableness-2," which inquires whether the defendant "manifests appropriate $e x$ ante concern on his part for [the] interests” the statute seeks to protect. ${ }^{121}$ When used in this context, Reasonableness- 2 does take into account the actor's individual traits. ${ }^{122}$ Moreover, it must do so because "Reasonableness-2 cannot rightly function as a measure of an actor's ex ante individual blameworthiness without making allowances for individual traits that, through no fault of his own, preclude him from forming the attitudes or beliefs regarding [the requirements of the relevant statute]."123 And so when the MPC inquires whether a person's allegedly negligent conduct constitutes a gross deviation "from the standard of care that a reasonable person would observe in his situation," ${ }^{, 24}$ we must inquire into the actor's particular traits. ${ }^{125}$

117. In fact, Westen contends there is no fact that is always relevant or always irrelevant in the reasonable person inquiry. See id. at 149. Although this Article does not explore it here, this assertion trades on two different readings of the word relevantone relating to causal efficacy and the other relating to the circumstances that should be captured by the reasonable person test.

118. Id. at 141 (footnote omitted). Note again that Westen presumes criminal statutes speak only in terms of results, rather than in terms of attendant circumstances or the nature of the conduct itself.

119. Id. at 142.

120. Id. at 145 .

121. Id. at $142-43$.

122. Id. at 143 .

123. Id.

124. Id. at 147 (quoting MPC $\S 2.02 \mathrm{cmt}$. (1985)) (internal quotation marks omitted).

125. Interestingly, Westen's distinction between Reasonableness-1 and Reasonableness2 collapses under a utilitarian framework: in both cases, the question is what factors, if included, would maximize preference satisfaction. Although Westen thinks one is about conduct and the other about blame, utilitarians do not make that kind of distinction a priori and would adopt it only if it led to the right sort of outcome. 
There is a lot going on here, but two points are worth highlighting. First, Westen is presupposing a rigid connection between a defendant's level of culpability and the extent to which he "manifests appropriate... concern" about the interests the statute seeks to protect. ${ }^{126}$ His account of culpability is, roughly, that it is a declaration that a person was not "motivated in his conduct by proper regard for interests that the law seeks to safeguard."127 Without this connection, there would be no reason to think Reasonableness-2 accurately captures culpability. Second, Westen presupposes a separate yet equally rigid connection between culpability and the "control principle"128 - the proposition that a person is responsible only for that which she has control over. ${ }^{129}$ Westen at times phrases it in terms of "making allowances" for traits that it is not the defendant's "fault" for having, but the underlying intuition is the same: we cannot blame a person for something that she could not control.

The application of Westen's Reasonableness-1/Reasonableness-2 distinction is meant to get some traction on the larger question this Article poses: What circumstances are relevant to the reasonable person inquiry? Or, in Westen's words, "Which of an actor's many traits are relevant to assessing his culpability ... ?",130 Reasonableness-1 is relatively straightforward-because it is meant to generate a particular standard of conduct, we need not include any of the defendant's personal characteristics. Reasonableness-2, however, which is meant to capture the actor's culpability, has to consider at least some of the actor's characteristics. Westen's argument on this point is worth quoting at length:

Since a "reasonable person” in negligence and voluntary manslaughter cases is an objective and personified standard by which to assess an actor's criminal blameworthiness, and since criminal blame is a judgment of an actor's values, it follows that a reasonable person in negligence and voluntary manslaughter

126. Westen, supra note 5, at 142-43.

127. Id. at 151. More on this account of blame later.

128. See Christopher Jackson, Tort, Moral Luck, and Blame, 60 Clev. ST. L. Rev. 57, 61-62 (2012).

129. E.g., Westen, supra note 5, at 147 (“[B]ecause an actor 'should' be aware of only what he can be aware ...."); id. at 141 (noting that a defendant always has a defense if "he nevertheless lacks the accompanying culpability that the statute requires"); $i d$. at 143 (using the language of "through no fault of his own"); id. at 143-44 (using blindness and being of below-average intelligence as factors that are outside of one's control and thus not blameworthy); id. at 144 ("To avoid blaming the blameless, the criminal law must be willing to make allowances for individual traits in assessing individual blameworthiness.”).

130. Id. at 148 (internal quotation marks omitted). 
cases is a construct that consists of all of what an actor is-including every physical, psychological and emotional trait-except that it also fully embodies the values of the people of the state as incorporated in the statute at hand regarding the rights and duties of persons. ${ }^{131}$

Westen is connecting his account of blame-a judgment about the actor's failure to appropriately take into account certain interests or values-to the reasonable person test as applied in cases seeking Reasonableness-2. Doing so, he suggests, resolves most of the thorny issues involved with the reasonable person test in the criminal law. Because Reasonableness2 incorporates all of an actor's traits, including those "that are not within his control and not his fault," it "avoids the problem of condemning actors for mental states or emotions they cannot help."132 Conversely, it does not excuse actors for traits they are capable of controlling because "while the test incorporates those faults, it expects actors to respond to them in the way that a person with proper values would respond to such dispositions - namely, by subjecting them to the controls and compensatory actions of which he is capable to prevent them from manifesting themselves."133 Thus, we have our answer. In the context of the criminal law, the reasonable person test can be broken down into two subissues. When we are concerned about Reasonableness- 1 and assessing conduct, we include no factors particular to the defendant. When we are dealing with Reasonableness-2 and assessing culpability, we include all of the defendant's particular characteristics, except that we imagine our reasonable person manifests appropriate regard for the interests the statute at hand seeks to protect.

\section{b. Critiquing Westen}

This Article focuses its criticism of Westen's theory on three points: the application of the reasonable person test to issues involving Reasonableness-1, his account of blame, and his formulation of the reasonable person test.

Beginning with Reasonableness-1, Westen argues that we need not incorporate any of the actor's characteristics when the reasonable person test is being used to determine whether the actor's conduct was wrongful. But even in cases where we are not using the reasonable person test to measure culpability, we will still have to make the inevitably difficult choices about which characteristics are relevant. If we adopt Westen's interpretation of the MPC's definition of recklessness and apply it to a

131. Id. at 151 (footnote omitted).

132. Id.

133. Id. at 152. 
homicide case, a guilty verdict would require a finding that the defendant was conscious of a substantial and unjustifiable risk and proceeded to act in the face of that risk. ${ }^{134}$ Even if we adopt Westen's position that the terms substantial and unjustifiable are "entirely a function of which risks the people of the state regard as acceptable and unacceptable," must still ask whether the people of the state would regard the risk as acceptable or not given the circumstances. That is, we cannot make the "objective" judgment that a particular risk is unacceptable without knowing the surrounding facts. This is true in the most basic sense that it would be impossible to describe what the risk is without making reference to at least some of the surrounding facts. For example, by saying that firing a gun risks another person's death, we have already filled out the situation to say that the act the defendant took was the firing of a gun and that doing so risked a causal chain of events leading to another's death. But more broadly, it would be impossible to evaluate a given risk without having some idea of the context surrounding it: the decision to fire a gun near an innocent bystander looks awfully unjustifiable until we take note of the fact that the person firing is a police officer and that she is doing it because an armed assailant is pointing his weapon at an innocent's head and is about to pull the trigger.

Westen might try to rely on a distinction between the internal characteristics of the defendant and the external facts of the situation. It is true, he might say, that we have to take account of the fact that the defendant is a police officer and that she is taking a shot to prevent the loss of an innocent life, but we will not be importing any circumstance about her. We can incorporate the external circumstances of the situation without considering the internal facts of the defendant herself. But this distinction is unavailing for the reasons laid out in Part III. ${ }^{136}$ The fact that the police officer is a police officer is a fact about the defendant, and the same goes for the fact that the police officer is either blind or able to

134. There is a little more at play in the way that Westen deals with the requirement that the defendant's conduct be a gross deviation from the conduct a lawabiding person would observe. But to avoid making the issue complex, it is enough to say that this Article's formulation is a necessary condition for a finding of recklessness, though not sufficient for such a finding.

135. Westen, supra note 5, at 145 .

136. See supra Part III; see also Jackson, supra note 1. 
see or that the defendant does or does not understand English. ${ }^{137}$ These facts are clearly relevant to an inquiry about recklessness and are equally clearly "about the defendant" or "internal" to her, rather than facts "about the situation” or "external” to her. As Westen recognizes, “' $[\mathrm{R}]$ isk' is an epistemic concept and, hence, is defined by reference to a real or imaginary person's viewpoint." "138 And because it is defined by reference to a particular viewpoint, it must take into account at least some facts about that viewpoint, thus making unavoidable our obligation to answer the question: which facts must it take into account?

Interestingly enough, the way we would go about determining which circumstances are relevant for Reasonableness- 1 is going to depend on what kind of conduct we consider wrongful. It is relevant that the assailant is about to shoot an innocent victim in determining whether it was reckless for a police officer to fire her weapon at the assailant, and it is relevant only because I am assuming that this kind of action-using force to save the life of an innocent at the expense of harming an aggressor-is not wrongful. My commitments in normative ethics also lead me to believe that the gender of the assailant does not change the outcome-whether the assailant is a man or a woman, the police officer's conduct is still justified. And as a result, we could safely read out gender of the assailant as a relevant circumstance. These examples are uncontroversial, but we could certainly manufacture some controversy by switching up the hypothetical. Suppose the police officer is taking aim at a doctor about to perform an abortion. In that case, whether we think the action is wrongful will depend in part on our views about abortion. And this of course just feeds back into the broader thesis of this Article: the circumstances we consider relevant in applying the reasonable person test will vary depending on the underlying theories we hold.

Westen's account of recklessness under the MPC presupposes a tight connection between his interpretation of recklessness and culpability. If inquiring into whether an actor was reckless does not require us to take into account any of the individual's particular characteristics-it is just whether or not she consciously disregarded a risk that society has determined is unacceptably large-and if the criminal law is meant to track blameworthiness - so that it would be wrong for the law to punish a person who is not culpable-then we have to assume that in any case where a person is reckless, she necessarily is blameworthy. In other words, there can be no case where a person is reckless but not to blame; otherwise

137. See Jackson, supra note 1 , at 11 ; supra p. 662. Another example might include the age of the defendant: what we consider reckless conduct in adults is probably not the same class of actions we consider reckless for a child.

138. Westen, supra note 5, at 144 n.32. 
the criminal law would be in the business of criminally punishing defendants for reckless conduct even though they are not culpable for their actions. ${ }^{139}$ Moreover, let us assume as Westen does that the control principle holds so that an agent is culpable only for that which she had control over. ${ }^{140}$ Then, we have a pretty strong assumption about the control principle: although one's failure to perceive a risk may or may not be in her control, one's disregard of a risk is always within her control. And there is no reason to think that this is true. It would not be very difficult to dream up scenarios where a person did in fact act recklessly but was not able to do otherwise. As Westen argues, we cannot hold a person responsible for that which she cannot control because doing so "would mean assessing the culpability of profoundly retarded actors like Of Mice and Men's Lennie by a standard of care that we know they cannot attain and are not at fault for failing to attain."141 The same argument applies in cases of recklessness: in what sense would it be fair to judge a person culpable for consciously disregarding a risk when we know she could not have done otherwise? ${ }^{142}$ Thus, I am skeptical that Westen's interpretation of recklessness, even coupled with a complete account of which circumstances are relevant, accurately tracks what the criminal law is up to.

The second major area of criticism in Westen's theory involves his account of blame. He begins by asserting that "[b]lameworthiness is a feature that persons reveal about themselves through their acts." 143 This strongly suggests that his definition of blame is character-based. But in the very next sentence, Westen says, "To publicly blame a person is to declare that he acted with a certain kind of motivation or attitude."144 This in contrast suggests that blame has much to do with a person's mental

139. See id. at 143.

140. See id.

141. Id. at 149 .

142. Westen seems to recognize the plausibility of this line of reasoning when he says that it would be a problem if a jury could not consider "difficulties that actors possess in controlling themselves that are neither within the actors' control nor their fault,” giving a war veteran suffering from PTSD as an example. Id. at 150. But he never delves into the issue or suggests how this does not pose a problem for his interpretation of recklessness. See id.

143. Id. at 151 .

144. Id. 
states. ${ }^{145}$ But Westen goes further, suggesting that blaming an actor "is to declare that he acted with a certain kind of motivation or attitude. Specifically, it is to adjudge that ... the person placed insufficient value on [the interests that the law seeks to safeguard]."146 And he interprets that to refer to mens rea-purpose, knowledge, recklessness, and negligence. ${ }^{147}$ Thus, Westen is quite ambivalent about whether blame tracks a person's character or her mental states. If he intends to equate mens rea and mental states more broadly with not placing sufficient value on the interests the state seeks to safeguard, then he is again making an implicit assumption that is rather hard to defend: that by acting with a particular mental state, you are demonstrating that you do not have a particular character trait-placing sufficient value on the right interests. And this is a dubious account of human action if only because there is such a thing as acting out of character. I might do some action and do it with a particular mental state, yet it still may be true that this has little to no bearing on whether I take certain interests seriously. ${ }^{148}$ I could, for example, take very seriously society's interest in protecting human life but still commit a murder out of pure rage.

The third and final critique of Westen's interpretation of the reasonable person test involves the way that he connects culpability to the test itself. Westen brings the two together under the rubric of Reasonableness-2: when the criminal law is inquiring about the culpability of the defendant and uses the reasonable person test, then the proper question is to ask what a person who possessed all of the defendant's characteristics would do, "except that [the reasonable person] also fully embodies the values of the people of the state as incorporated in the statute at hand regarding the rights and duties of persons."149 Presumably, if the two conflict so that one of the defendant's characteristics is a failure to properly respect the state's values, the state's values, rather than the defendant's, trump. The idea behind this formulation is that because blameworthiness is a judgment of the actor's values, in criminal law the thing that we are blaming

145. It seems possible to argue that the thing a person reveals about herself through her acts is just the motivation that she acted with. But that is a strained reading of the text and one at odds with Westen's larger point, as discussed below.

146. Westen, supra note 5, at 151.

147. Id.

148. Westen might be trying to say that by acting in a certain manner I have evidenced that I do not take the relevant values seriously to the extent that I performed that particular action. But I think he is going to want to avoid this formulation because doing so essentially collapses the distinction between mens rea and placing value on particular interests, which would call into question his ultimate formulation of the reasonable person test.

149. Westen, supra note 5, at 151. 
a defendant for is his failure to properly respect the values we have decided are important by enacting the criminal code. But it is very difficult to determine which values the people have embedded in the "statute at hand." 150 Without going into too much detail, what, for example, does a defendant fail to respect by violating a regulatory offense? Is it respect for the state's law? The importance of being part of a regulatory regime that brings about a better state of affairs? It is intuitively possible-and indeed likely - that the reason why the state chose to criminalize some conduct is not the same reason that we think a person is blameworthy for engaging in it. ${ }^{151}$

In any case, the primary issue I want to address is that Westen's test is both underinclusive and overinclusive. It is underinclusive because it fails to account for characteristics that are at odds with society's values with respect to the statute at hand but still outside of the defendant's control. Westen adheres closely to the control principle: it would be unjust, he argues, to hold blameworthy an actor who could not have done otherwise. ${ }^{152}$ But the reasonable person test as applied to Reasonableness-2 holds actors responsible for that which is not under their control. It is possible to fail to show appropriate respect for society's values and not have any control over this failure. Consider Westen's treatment of State v. Williams, ${ }^{153}$ where two Native American parents of below-average intelligence were convicted of manslaughter for the death of their infant son after they failed to seek medical care for several weeks for an abscessed tooth that eventually developed into pneumonia. ${ }^{154}$ Westen provides sample jury instructions

150. Id.

151. One pertinent example comes from a hypothetical case posed in an environmental crimes class. In breach of the Clean Water Act, the defendant dumped thousands of gallons of gasoline down the sewer on a street corner, which put the children attending a nearby elementary school in serious jeopardy because the gasoline was sufficiently concentrated that it was liable to ignite and explode. In that case, the reasons that the defendant was blameworthy do not track at all the values the Clean Water Act was meant to instantiate when Congress passed it into law. See 33 U.S.C. § 1251(a) (2006) (stating that the goal of the Clean Water Act "is to restore and maintain the chemical, physical, and biological integrity of the Nation's waters").

152. Westen doubles down on this theory when he says, "The test thus avoids the problem of condemning actors for mental states or emotions they cannot help.” Westen, supra note 5 , at 151 .

153. 484 P.2d 1167 (Wash. Ct. App. 1971).

154. Id. at 1169-70, 1173; see also Westen, supra note 5, at 152-53 (discussing the State $v$. Williams decision). 
that are meant to be a practical application of his thesis to the crime of negligent homicide. The jury is to be told,

[Y]ou must determine whether it was reasonable for it not to have occurred to [the defendants] that William's life might be in danger. To do so, you shall take into account everything you know about [the defendants] —including their education, experience with ... children, their level of intelligence, their ethnicity-with one exception. [Y]ou shall reserve judgment about whether [they] are telling the truth when they say how much they loved and cared about William's physical well-being .... [Y] Washington expect every parent to care deeply and continually about his or her child's continued survival . . . .155

But what if it turns out that the defendants did not care "deeply and continually about" their child, yet they could not have done otherwise? In such a case, Westen's adoption of the control principle cannot be reconciled with his interpretation of the reasonable person test. Paradoxically, the more values the criminal law expresses, the less we may take into account the defendant's personal characteristics and, on Westen's interpretation, the more likely it is that we will criminally punish a defendant who is not to blame for her actions.

Similarly, Westen's theory is overinclusive because it permits consideration of traits that are the actor's fault for having. There are certain features about me that are my fault because I have either cultivated them or failed to cultivate better traits. It would be my fault for having a hot temper if I have cultivated that trait and likewise my fault if I have a hot temper even though I could have taken steps to overcome that traitby, say, taking anger management classes. There would therefore be no reason to take those traits into account in applying the reasonable person test. If I am disposed to random bouts of violent rages but am able to control these outbursts, there is little reason to think that, if I am charged with reckless murder, the jury should consider what a reasonable person prone to violent rages would have done. But under Westen's view, so long as these traits do not conflict with the values the statute at hand was meant to instantiate, they must be included in the reasonable person test. Westen tries to respond to the criticism:

[T]he test also avoids the problem of excusing actors for faults of character they are capable of controlling or compensating for, because while the test incorporates those faults, it expects actors to respond to them in the way that a person with proper values would respond to such dispositions - namely, by subjecting them to the controls and compensatory actions of which he is capable to prevent them from manifesting themselves. ${ }^{156}$

155. Westen, supra note 5, at 154-55.

156. Id. at 151-52. 
But this only narrows the applicability of the criticism; it does not avoid it all together. The list of things that I am capable of controlling does not perfectly correspond to the list of things that society values. There are still some things that I am responsible for that are not covered by society's values instantiated by the law. And there is no reason those should be included in the reasonable person test. Think again to an aggressive temperament, or perhaps more egregiously, to harboring racist attitudes. It could hardly be right to say that a person charged with reckless murder must be compared to the violent person or the reasonable racist. ${ }^{157}$ And it is no answer to say that the state's laws, broadly construed, also evidence values contrary to racism. First, we can imagine a state that has not passed any laws with respect to racism. Second, this makes the application of the reasonable person test all the more difficult: how could we know all of the competing values that the law of the state-from tort to the criminal code to regulatory offenses to the state's constitution-is meant to embody or how to commensurate those oft-competing values? Westen himself refers only to "the statute at hand," and my hunch is that he does so to avoid these concerns. ${ }^{158}$

The heart of my objection on grounds of both overinclusiveness and underinclusiveness rests on Westen's peculiar account of blame. There is a significant tension between his adoption of the control principle and his assertion that blame is about an agent's failure to take into account particular values. My criticism would have significantly less bite if Westen reformulated his theory of blame. And this observation leads me into the final subpart of this Article's discussion on blame-based accounts of the criminal law: some lessons that we can draw from the foregoing discussion.

157. See Armour, supra note 24, at 787-88. Jeremy Horder offers another example: "[I]n a duress case, a threat to terminate a pregnancy by kicking the defendant in the stomach can hardly be properly assessed ... without taking into account that that person is a pregnant woman.” Jeremy Horder, Can the Law Do Without the Reasonable Person?, 55 U. TORONTO L.J. 253, 264 n.36 (2005).

158. Westen, supra note 5, at 151. Though there is one significant inconsistency: In proffering the jury instructions in Williams, Westen makes the undefended assertion that it is Washington State's considered judgment that parents always care deeply about their children. Id. at 155. It certainly is not obvious that this is found in Washington's manslaughter statute. 


\section{c. Lessons \& Other Theories}

I have spent a fair amount of time analyzing and critiquing Westen's account of the reasonable person in the criminal law. I have taken this approach partly because his theory is rich enough to warrant sustained dialogue but also because doing so motivates the broader discussion. Recall the hypothesis, set out in the beginning of Part IV.A.1, that if we adopt a blame-based view of the criminal law, the factors relevant to the reasonable person test will depend on whether the inclusion or exclusion of a given factor will more accurately capture blameworthy conduct. We considered Westen's theory of blame and his application of that theory to the reasonable person test, and we saw that his account of blame drives his application of the reasonable person test to the criminal law. The problems with his theory are dependent on his definition of blame; a different interpretation of blame would yield a different kind of reasonable person test-one that perhaps would not run into the same problems. And there are other theories of blame on the table. Blame might not be about whether one appropriately takes into account certain interests but about whether she engaged in wrongful conduct, or about her intentions, or the kind of character that she has, ${ }^{159}$ or perhaps something else altogether. Depending on which theory we adopt, our interpretation of the reasonable person test will differ.

To see how this works in practice, let us take a step back from Westen's particular theory of blame and look to see what other ways academic commentators have analyzed the reasonable person. A survey of the literature demonstrates that Westen was not alone in adopting the control principle-it is extraordinarily common. ${ }^{160}$ There is a continuous struggle

159. For one example, see George P. Fletcher, The Individualization of Excusing Conditions, 47 S. CAL. L. REv. 1269, 1288-92 (1974). Fletcher argues quite forcefully that the "only one sound way to determine the traits attributed to the reasonable man ... is with an eye to the justice of blaming the accused for having displayed weakness of character." Id. at 1292.

160. E.g., MORAN, supra note 4, at 26 (arguing that there is a "tight relationship" between blameworthiness and legal fault when "the reasonable person is sufficiently infused with the characteristics of the litigant"); Armour, supra note 24, at 801 ("Insofar as a defendant can claim that 'I couldn't help myself,' she cannot be blamed for her reactions, regardless of the subject of her disorder.”); Fletcher, supra note 159, at 1291 \& n.70 (discussing the control principle directly); Horder, supra note 157, at 266-67 ("[I]f liability is to be fault-based, why blame those who cannot help their mental deficiency when we do not blame those who cannot help their physical deficiency?”); Lee, supra note 43 , at $381 \&$ n.34, 385 ("[A] subjectivist might argue that one deserves to be punished [for attempted murder] to the same extent as if one killed the other person because all that matters are acts that one can control." (citing Larry Alexander, Crime and Culpability, 5 J. Contemp. Legal Issues 1, 30 (1994); Arenella, supra note 37, at 831 n.21)). But see Robinson, supra note 7, at 306 (asserting that taking into account all 
to try to draw the line between factors that are under a person's control and those that are not. Take as an example Mayo Moran's argument that the common law is inconsistent in the way it treats the physically and the mentally challenged. ${ }^{161}$ As Jeremy Horder succinctly summarizes, "If I am blind, I cannot be judged, qua defendant, as if I were a sighted person; and my needs, qua plaintiff, cannot be ignored by those responsible, for example, for leaving obstacles on the sidewalk."162 But in contrast, "if it is mental disability that explains some shortcoming on my part, the common law studiously ignores the disability in determining liability questions."163 Moran's critique is centered firmly on the control principle: she argues that "[t]he treatment of mental disabilities is controversial precisely because of the disconnect that occurs between legal fault and moral blame."164 She criticizes the law for "imposing the rigid standard on only one group of 'incapable' individuals."165 Phrased differently, "someone whose mental abnormality prevents them from recognizing and hence avoiding the harm in question cannot be morally blameworthy."166 The intuition is that there is no defensible way to fill out the phrase "under one's control” that excludes physical disabilities but includes mental ones. The law's implicit attempt to do this fails, and so we ought to reject or modify it in some way. ${ }^{167}$

This kind of argument gets repeated throughout the literature, with different commentators discussing different examples of cases where the law inconsistently applies the control principle. And so Horder discusses

of the defendant's characteristics “would turn [the reasonable person test] into a purely subjective standard, which would fail to make the blameworthiness judgment the law seeks”).

161. See MoRAn, supra note 4, at 18-57.

162. Horder, supra note 157, at 266.

163. Id.

164. MORAn, supra note 4, at 32.

165. Id. at 34 (emphasis added).

166. Id. at 38 .

167. See id. at 314. Even when Moran proffers her alternative to the reasonable person test-suggesting we instead ask whether the defendant was "culpably indifferent" - she is still open to criticism on grounds of the control principle. She writes that there is a difference between "a credible claim by an individual that he did not have the intellectual capacity to perceive the relevant risk, as opposed to a similarly credible claim that an individual did not have the moral resources to care about imposing the harm." Id. at 26-27. But this only pushes the question back a step: one could rightly point out that the very fact that she did not have the moral resources to care about imposing risks was outside of her control in precisely the same way that lack of intellectual capacity is. This is exactly the same problem Westen faces, discussed above. See supra text accompanying notes $112-129$. 
Moran's work on the distinction between physical and mental disabilities and wonders whether we should "mak[e] yet further refinements to the reasonable-person standard" or instead "replace that standard" with a different test all together. ${ }^{168}$ Paul Robinson distinguishes the way the law treats a defendant's "certifiably bad temper" from "a genetic predisposition toward violent reaction when provoked," though both "seem beyond the actor's control."169 Fletcher questions why the duress defense is not available as a defense to homicide under the common law, though there can be an equally strong argument that the defendant's conduct was out of his control. ${ }^{170}$ He also suggests that although ordinary cowardice and selfishness cannot excuse criminal behavior, having "some discernible pathology to cause us to believe that ... [he] could not have done otherwise" would be relevant. ${ }^{171}$ Lee wonders why the law makes a distinction between a person who intends to kill but fails and the one who intends to kill but succeeds, even though the only one that matters for purposes of criminal culpability "are acts that one can control." 172 And Armour argues that there are no factual distinctions that "meaningfully distinguish the battered woman's claim from that of the negrophobe for the purpose of [invoking self-defense]." ${ }^{\text {173 }}$ The infamous Bernie Goetz case-where a man shot four African American teenagers in the subway and claimed selfdefense, relying in part on the fact that he had been mugged previously ${ }^{174}$ poses precisely the same problems. ${ }^{175}$ Indeed, much of the confusion surrounding the reasonable person test, from arguments about so-called cultural defenses to run-of-the-mill provocation cases, arises out of this concern.

What is interesting about these and other commentators who follow this general line of thinking - the control principle has an important place in criminal law, yet the law does not consistently apply it-is that there is little explicit recognition that they are pushing up against the eons-old free will debate. In what sense are any of my traits "under my

168. Horder, supra note 157, at 266-67.

169. Robinson, supra note 7, at 306.

170. See Fletcher, supra note 159, at 1278-79.

171. Id. at 1291.

172. Lee, supra note 43, at 385-86. Lee does not necessarily buy into the control principle - she discusses the possibility of "instrumentalist" defenses of criminal lawbut she raises the issue as part of this larger discussion.

173. Armour, supra note 24, at 804.

174. See People v. Goetz, 497 N.E.2d 41, $43-44$ (N.Y. 1986).

175. Though the case has been written about ad nauseum, see, for example, Armour, supra note 24 , at $781-85,805$. 
control"? Can I not concoct a causal story that explains everything about me and thereby excuse myself entirely from moral judgment? ${ }^{176}$

We are now at a point to reach the conclusion this discussion has been building toward. We have seen that academic commentators discuss the reasonable person test in the context of their adoption, whether explicit or implicit, of the control principle. Under a blame-based view of the criminal law, they assume that a necessary condition to blame a defendant is that her conduct was "under her control." And the way that we fill out the phrase "under one's control" will straightforwardly affect the way the criminal law applies the reasonable person test to a given case. If I conclude that it is under my control whether my bad temper leads me to act violently but not under my control whether my mental defect causes me to engage in the same conduct, then the circumstances that are relevant to the reasonable person test will exclude my bad temper but include my mental defect. In other words, the list of factors that are not under one's control will be those that are relevant to the reasonable person test. Though they do not explicitly cast their work in these terms, the commentators discussed above are grappling with the question of what exactly is under a person's control; they cannot resolve the way the reasonable person test applies without first getting a good grasp of how the control principle works in practice. And so we see again that the factors relevant to the reasonable person inquiry will vary based on the underlying theory one takes to justify a particular area of law.

We now know that if we adopt the control principle and adhere to a blame-based view of the criminal law, the factors that are relevant to the reasonable person test are dependent on how we fill out the phrase "under one's control.” But briefly I would like to open up another possibility that is much discussed in the philosophical literature but rarely if ever referenced in the legal community with respect to the reasonable person test. We might hold fast to a blame-based view of the criminal law while

176. These issues involving the control principle are mediated through the criminal law, and there may be sound ways to distinguish the function of the criminal law from the social practice of blaming. Armour notes that there are "instrumentalist" theories of law, which focus on the way a legal rule furthers the broader interests of society, rather than a noninstrumentalist theory, which focuses on individual culpability. See id. at 814-15. 
simultaneously rejecting the notion that one can be responsible only for that which is under her control.

Though rejection of the control principle is counterintuitive, it may be the best response-perhaps out of a collection of pretty abysmal responses - to the problem of free will. Rather than detouring into a quixotic attempt to say anything novel about the free will debate, this Article will cover one theory that takes this route to fill out the proposition. There are a host of ways to respond to the problem of free will, broken down roughly into the incompatibilists, who believe that if the universe is deterministic, moral responsibility is impossible, ${ }^{177}$ and the compatibilists, who believe that even if the universe is deterministic, moral responsibility is still possible. Compatibilism breaks down further into a series of competing subtheories about just how it is that determinism and moral responsibility coexist. To pick one I am sympathetic to, Harry Frankfurt rejects the control principle out of hand ${ }^{178}$ and suggests that moral responsibility can be grounded in the fact that human beings have "second-order desires"-desires about the desires that they have-and that "the capacity for reflective self-evaluation ... is manifested in the formation of [those] second-order desires." ${ }^{179}$ He conceives of an agent's will as those desires by which he is motivated in some action or "by which he will or would be motivated when or if he acts." words, are just those desires that are causally efficacious. Freedom of the will, then, is the ability to choose what constitutes your will; "the statement that a person enjoys freedom of the will means ... that he is free to want what he wants to want. More precisely, it means that he is free to will what he wants to will, or to have the will he wants."181 Although it is theoretically possible for a person to formulate desires of higher and higher orders, for example, I want that I want that I want .. . that $X$, "[w]hen a person identifies himself decisively with one of his first-order desires,

177. Libertarian incompatibilists, who believe that the universe is not deterministic and that moral responsibility is possible, adhere to the incredible view that "[w]henever a person performs a free action ... it's a miracle.... A free agent has, therefore, 'a prerogative which some would attribute only to God: each of us, when we act, is a prime mover unmoved." Harry G. Frankfurt, Freedom of the Will and the Concept of a Person, $68 \mathrm{~J}$. PHIL. 5, 18 (1971) (quoting Roderick M. Chisholm, Freedom and Action, in FrEEDOM AND DETERMINISM 11, 23 (Keith Lehrer ed., 1966)).

178. For Frankfurt's explicit argument that the control principle itself should be rejected, see Harry G. Frankfurt, Alternate Possibilities and Moral Responsibility, $66 \mathrm{~J}$. PHIL. 829, 829-30 (1969).

179. Frankfurt, supra note 177 , at 6-7.

180. Id. at 8 .

181. Id. at 15. 
this commitment 'resounds' throughout the potentially endless array of higher orders" and can serve as the basis for moral responsibility. ${ }^{182}$

On Frankfurt's view, the reasonable person test would be applied quite differently than Moran, Horder, Armour, and others have suggested. Rather than asking whether a particular factor is under the defendant's control, Frankfurt would ask whether the person's second-order desires lined up with her first-order ones. Thus, the addict who wants to be an addict would be treated differently from the addict who wishes that she were not an addict, though we would say in both cases that the decision to take drugs was not under her control. ${ }^{183}$ I hesitate to delve any deeper in discussing how the reasonable person test works under Frankfurt's theory in particular; the only takeaway point is that there are alternatives to retributivist theories that do not rely on the control principle, and they should be seriously considered.

\section{B. Tort Law}

This Article has given some insight into the ways that the reasonable person test is applied in the context of the criminal law. The list of factors that are relevant will depend on what justification underlies the criminal justice system-utilitarians will have a different set of factors than retributivists, and there will be greater variation still about the way that we fill out each of those theories. Turning now to tort law, this Article will approach the topic in a similar way, considering two competing theories: corrective justice and law and economics. In the above discussion of the criminal law, I gave several examples of how the reasonable person test is used, including in the definitions of recklessness and negligence and the elements of a self-defense claim. Rather than cataloguing the various ways the test pops up in tort law, I note only the most obvious: negligence actions lie where a defendant proximately harms another by failing to act as a reasonably prudent person would under the circumstances. ${ }^{184}$

182. See id. at 16.

183. See id.

184. E.g., RESTATEMENT (ThiRD) OF TORTS: LIABILITY FOR PHYSICAL AND EMOTIONAL HARM $\S 3 \mathrm{cmt}$. a, § $6 \mathrm{cmt}$. b (2010). 


\section{Accident Costs}

Because much of what I say here will dovetail with my discussion of utilitarianism in Part IV.A.1, my treatment of the economics approach to tort law will be short, focusing on the differences between the two subjects. ${ }^{185}$ Economic theorists adhere to the principle that the best way to understand a particular area of law is to view it through the lens of a particular methodology: utility maximization. ${ }^{186}$ In tort law, economists usually equate utility maximization with the efficient reduction of the costs of accidents. ${ }^{187}$ It is a nonobvious proposition that utility maximization means, in the realm of tort law, the efficient reduction of accident costs, ${ }^{188}$ but that is the way that most practicing economists approach the subject. ${ }^{189}$ Calabresi "take[s] it as given that the principal functions of 'accident law' [that is, tort law] are to compensate victims and reduce accident costs."190 Steven Shavell's work Economic Analysis of Accident Law ${ }^{191}$ similarly assumes that tort law is about accident costs rather than utility broadly construed.

There is a lot more to fill in to have a solid understanding of how an economist would approach a particular case in tort law. As an empirical matter, it is very difficult to determine what tort rules would lead to the most efficient reduction of accident costs. We would have to trace out all of the causal connections that the implementation of a given set of rules would have on those costs and then compare the total costs produced by that set of rules to the costs produced by every other set we might conceivably adopt. Economists have spilled a great deal of ink trying to figure out what the optimal rules are ${ }^{192}$ and that the only takeaway point is that, as we saw in the context of utilitarian approaches to criminal law, I doubt we will ever be able to approach a definite answer.

185. Utilitarianism and the economics movement within torts are closely related: "The scholarly tradition from which the positive economic theory of tort law emerged begins with Jeremy Bentham ....” William M. Landes \& Richard A. Posner, The ECONOMIC STRUCTURE OF TORT LAW 4 (1987).

186. Don Herzog, Externalities and Other Parasites, 67 U. CHI. L. REv. 895, 895 (2000).

187. E.g., Guido Calabresi, The Costs of Accidents: A Legal AND ECONOMIC ANALYSIS 26 (1970); LANDES \& POSNER, supra note 185, at 1.

188. For an in-depth discussion on this issue, see Hershovitz, supra note 94, at 75; see also Jackson, supra note 128 , at 84 \& n.119 (discussing utility maximization).

189. See sources cited supra note 187.

190. Guido Calabresi, The Decision for Accidents: An Approach to Nonfault Allocation of Costs, 78 HARV. L. REV. 713, 713 (1965).

191. STEVEN SHAVELL, ECONOMIC ANALYSIS OF ACCIDENT LAW 3 (1987).

192. See, e.g., 1 TORT LAW AND ECONOMICS (Michael Faure ed., 2d ed. 2009). 
Putting to one side the empirical issues, economists have tough questions to answer with respect to their theory as well. First, they have to determine which costs fall under the term accident costs, and the content of that list is far from self-evident. Although things like hospital bills and lost wages are easily included, it is not so clear when we talk about psychological injury or personal inconvenience or that a certain state of affairs is unfair. The term costs can cover any causal effect flowing from an accident, and the decision of whether to call them costs is a normative one with which economists rarely grapple. ${ }^{193}$ Second, the term efficiency could be defined in a number of ways. It could simply mean the lowest total of costs, but it also might refer to Pareto efficiency, where an allocation is optimal if at least one person is made better off without making any other person worse off. ${ }^{194}$ Or it could mean Kaldor-Hicks efficiency, where a change in distribution is optimal if the person who gains an advantage has enough to compensate those who were made worse off, even if she never does. ${ }^{195}$ There is nothing inherent in the economics approach that would prefer one interpretation over the other, so again economists have to grapple with questions of value that will not be answered by appeals to economic models.

Finally, the economist will also have to contend with the possibility that the most efficient set of rules in tort law is radically different than what tort law looks like today. For example, there is little reason to think that the reasonable person test is the single most efficient way of assessing civil liability. Perhaps some kind of social insurance scheme would be a cheaper way to reduce the costs of accidents. If that is the case, the economics approach might have to abolish the reasonable person test altogether. ${ }^{196}$ Similarly, even if the economist does incorporate the reasonable person test into her version of tort law, the circumstances

193. For a discussion about certain costs that law-and-economists have tended to overlook, see Hershovitz, supra note 94. For the same reason, it is not obvious what kind of scenarios the term accidents covers.

Note that in Part IV.A.1, I largely assumed away these questions. I chose preference utilitarianism as the starting point. That theory holds that preferences are the only things we are concerned with maximizing, and maximize just means satisfying the greatest number of those preferences.

194. Nicholas BarR, The Economics of the Welfare State 43-45 (5th ed. 2012).

195. LANDES \& POSNER, supra note 185, at 16.

196. There is no way to automatically discount this possibility in any field of law and in any theory of a given field. A blame-based view of criminal law might likewise preclude the use of the reasonable person test in assessing liability for negligent or reckless conduct. The only difference is that in the utilitarian or law and economics context, that outcome would be governed by empirical, rather than theoretical or normative, considerations. 
that are relevant might still be radically different than any common sense view of what the test involves. It might turn out that it is inefficient to include the brute physical facts of the circumstances, such as the speed of the car that hit a pedestrian, in assessing whether the defendant was negligent, even though these kinds of facts are relevant under any intuitive reading of the reasonable person test.

Having set out the basics of the economics approach to tort law, we can apply these principles to the reasonable person test. A circumstance would be relevant to the test if its inclusion would lead to the most efficient reduction of accident costs, and it would be irrelevant if its inclusion would not lead to the most efficient reduction of those costs. So, for example, if tort law defines accident costs as "economic costs," efficiency as "maximization," then we would want to include those factors that most reduce the economic costs associated with accidents, paying no attention to the way in which those costs are distributed. We would make arguments like 'The inclusion of the fact that the defendant was a child would make it harder for a victim to recover from a child in a negligence action. This in turn would incentivize people to take greater care to avoid accidents when they are around children, which would reduce the costs of such accidents.' In reality this argument would be far too simple: there is no empirical proof that the incentive would have any causal effect; there is no indication as to what kind of or how much cost this incentive would reduce if it did have that causal effect; there is no consideration of any unintended consequences that might result from this rule; and so on.

As we saw with utilitarian approaches to criminal law, the questions involved are straightforward in theory but difficult to apply in practice. Given the stunning complexity involved in tracking down each and every effect a given set of rules has on accident costs, I am skeptical that we can say much more than this: there must be a causal connection between the inclusion of a particular factor in the reasonable person test and the amount or distribution of accident costs. ${ }^{198}$

197. Admittedly, the term economic costs is awfully vague; I mean to suggest the inclusion of hospital bills, lost wages, damage to property, and the other sorts of things we traditionally think can be transferred through markets. To the extent someone might argue this is not a coherent way to distinguish relevant costs from irrelevant ones, I plead guilty and point out that this is precisely the trouble law and economics theorists are going to have when they try to create a model for tort law.

198. The logical relationship I have in mind is that for a given factor to be relevant to the test, it must be a necessary condition to some set of sufficient conditions to affect the distribution or amount of accident costs-satisfaction of the so-called "NESS test." See, e.g., Richard W. Wright, The NESS Account of Natural Causation: A Response to Criticisms, in PeRsPeCtives on CAUSATION 285, 285-86 (Richard Goldberg ed., 2011). 
This discussion gives some idea of the way an economist would approach the question of what circumstances are relevant to the reasonable person test. As this Article shall explore, the corrective justice approach to tort law will apply the reasonable person test in a significantly different manner.

\section{Corrective Justice}

The dominant competing theory to the economist interpretation of tort law is corrective justice. The term corrective justice is an umbrella term that covers a number of divergent theories. Stephen Perry has laid out a taxonomy that categorizes the various possibilities. ${ }^{199}$ For purposes of this discussion, I will, without argument, adopt one particular interpretation of corrective justice.

Elsewhere I have discussed what I called an "obligations-based view" of tort law, ${ }^{200}$ which holds that the kind of conduct that gives rise to a duty to repair is that which we are morally obligated not to do. In other words, "when we are deciding what kinds of actions constitute tortious conduct ... we should look to normative ethics." 201 In the same way that, at least according to the theory discussed in Part IV.A.2, criminal law bears a strong connection to moral culpability, tort law bears a strong relationship to conduct-governing rules. In Perry's parlance, this theory falls under the second type of corrective justice-that which holds that the duty to repair is not a social obligation but one that "involv[es] a limited moral relationship that holds only between injurer and victim."202 In some situations, the fact that $A$ caused $B$ injury gives rise to an obligation in $A$ to compensate $B$. And the phrase "in some situations" is filled out by the content of our duties under the moral law. At the same time, it is ambivalent between Perry's fault-based local redistributive theory, where it is the fact that $A$ acted wrongfully that grounds his obligation to compensate $B,{ }^{203}$ and his fault-based volitionist theory, where it is $A$ 's engaging in voluntary wrongful action that gives rise to his obligation to compensate $B .{ }^{204}$ The obligations-based view finds convincing the

199. Stephen R. Perry, The Moral Foundations of Tort Law, 77 IowA L. REv. 449, 449 (1992). Perry himself adopts a hybrid view where the localized distributive argument and the strict liability volitionist theory "are complementary." Id. at 497.

200. Jackson, supra note 128, at 72.

201. Id.

202. Perry, supra note 199, at 449.

203. See id. at 467-68.

204. See id. at 474-75. 
arguments that draw a distinction between evaluating an action and evaluating a person, ${ }^{205}$ or what the literature sometimes describes as the distinction between normative and ascriptive rules, where the question of "what I may do or ought not to do" is distinct from whether I am morally blameworthy. ${ }^{206}$

We are now in a position to see what the obligations-based view has to say about the factors relevant to the reasonable person inquiry. The reasonable person test is used in negligence cases to determine whether or not the alleged tortfeasor has violated a duty owed to the plaintiff. The obligations-based theory holds that a person's duties under tort law are just those things that she has a moral obligation to do or not to do. ${ }^{207}$ Thus, the factors that are relevant in the reasonable person test are those factors that, if included, would have the test track our moral obligations. ${ }^{208}$ But to figure out which factors those are, we have to dig deeper and get a handle on what an actor's moral obligations are. ${ }^{209}$ There is obviously

205. See id.
206. Horder, supra note 157, at 265 . Fletcher notes that one's capacity for selfcontrol, sanity, level of intoxication, and motive for action are all irrelevant in determining liability for intentional torts. See George P. Fletcher, The Theory of Criminal Negligence: A Comparative Analysis, 119 U. PA. L. REV. 401, 408 (1971). This tracks well with the view that tort law-perhaps even in the intentional tort context-involves normative rather than ascriptive rules. See McHale v Watson (1964) 111 CLR 384, 397 (Austl.) (holding that children are judged by a more "subjective" test because tort is about propriety, not blameworthiness).

Moran seems to think that, at least in the context of tort law, this distinction does not hold much weight. In critiquing what she calls the "compensation rationale" for tort, Moran recognizes that many tort scholars ground their theory in the idea that tort "is understood primarily as a compensation scheme and fault is seen as an appraisal of acts, not actors." Moran, supra note 4, at 34 (emphasis added). But she rejects this idea, asking, "[W]hat exactly is the content of this non-culpable fault?” $I d$. at 36. She contends that there is no satisfactory answer to this question and that any conception of fault in tort law must rely in some sense on culpability. See id. at 36-39. There is quite a bit going on in this discussion, but for now it is enough to say that (1) many corrective justice theorists would dispute that fault must always be about culpability, and (2) Moran is, like so many other tort theorists before her, implicitly relying on the control principle. See id.

207. See Jackson, supra note 128 , at 72.

208. Of course, tort law does not recognize a duty to perform all of our moral obligations. There is no duty in tort to lie, absent other conditions, or to be faithful to one's partner, or to develop one's skills, though these are clearly moral obligations we have. The obligations-based view is analogous to a blame-based view of criminal law, where there is a strong correlation between what we are to blame for and what we are criminally liable for, though not a perfect one.

209. Or we, at least, need to get a handle on which moral obligations we have that tort law will recognize. See supra note 208. It is an open question which obligations the tort law will recognize, but because that issue revolves around questions of political theory, it is beyond the scope of this Article. 
much disagreement about that question, depending as it does on one's underlying commitments in both normative and applied ethics.

One particularly interesting application of the obligations-based view comes from its treatment of defenses such as insanity. Under common law, neither infancy nor insanity is a defense to an intentional tort. ${ }^{210}$ And courts have usually held that the same rule applies in the context of negligent actions. ${ }^{211}$ Whether claims of insanity would factor into the reasonable person test would depend on the way we characterized insanitybased defenses. If the idea is that an insane person, in committing an act we ordinarily would consider wrongful, did in fact do something wrong but is not to blame for it, a "culpability-exculpating excuse," then it would have no place in tort law. The obligations-based view holds that tort instantiates a system of compensation based on wrongful acts, irrespective of whether the person who committed the act is to blame for what she did. If, on the other hand, the idea is that the insane person's allegedly wrongful conduct was not in fact wrongful-if, because she was insane, she breached no moral obligation, a "duty-exculpating excuse," ${ }^{\text {,12 }}$ then insanity would be relevant in assessing whether a tort action lies. To determine whether insanity is a culpability-exculpating or a duty-exculpating excuse, one would have to determine whether the defendant, as a result of her insanity, is not properly a person subject to the strictures of the moral law. ${ }^{213}$

The argument with respect to age would be similar: age could be conceived as either culpability-exculpating or duty-exculpating, though my hunch is that it is the latter. Children, or at least very young children, do not have the same sorts of obligations to take reasonable care that adults do. ${ }^{214}$ The broader point is that the way society determines which circumstances are relevant to the reasonable person test is dependent on

210. E.g., McGuire v. Almy, 8 N.E.2d 760, 763 (Mass. 1937); Patrick Kelley, Infancy, Insanity, and the Law of Torts, 48 AM. J. JuRIS. 179, 181 \& n.6 (2003).

211. E.g., Note, Tort Liability of the Mentally Ill in Negligence Actions, 93 YALE L.J. 153, 153 \& n.1 (1983).

212. There is a high but not perfect correlation between what this Article calls a "duty-exculpating excuse" and a justification.

213. An excuse could also be both duty-exculpating and culpability-exculpating. If I think that very young children do not have moral obligations, I certainly do not think they are to blame for failing to follow an obligation that does not bind them.

214. See P. F. Strawson, Freedom and Resentment, 48 PROC. BRIT. ACAD. 187 (1962), reprinted in P. F. STRAWSON, FREEDOM AND RESENTMENT AND OTHER EsSAYs 1, 8-11, 19 (1974). 
our underlying commitments-this time in the realm of ethics. Just as the blame-based view of criminal law devolved into a series of competing subviews that debate the control principle's connection to moral responsibility, under the umbrella of an obligations-based view of corrective justice, there is plenty of room for disagreement in the particulars. Without addressing our disagreements on that level, there is little hope we will ever arrive at a satisfactory answer about the reasonable person test.

This Article discusses an obligations-based theory of tort not just because I find it persuasive but also because it is easier to see the way in which the theory drives the determination of which circumstances are relevant to the reasonable person test. The connection relates to one's commitments in normative and applied ethics. But for other theories of corrective justice, the connection is not so clear-cut. There are two ways that the connection between the reasonable person's circumstances and the underlying corrective justice theory come apart: when the theory suggests we should scrap the test altogether and when the theory is, in a relevant sense, incomplete. To see how the first works in practice, let us turn to a model Richard Epstein has propounded ${ }^{215}$ — what Perry calls the "restitution" theory - which says that " $A$ has come into possession of something that belongs to $B$ and hence must give it back."216 Epstein suggests that "torts themselves are a sub-class of takings." ${ }^{217}$ By engaging in a tortious act and causing injury, the tortfeasor has taken something from the victimsomething the victim has a property right in —and it is this fact that gives rise to $A$ 's obligation to compensate $B$. By now it is obvious that the reasonable person test does not so easily map on to the restitution theory's sense of the duty prong of a common law negligence claim. If Epstein is right that tort is about compensating for the wrongful interference of a property right, then it is not clear why we need a reasonable person to tell us when the tortfeasor has violated his duty. The question is not how a reasonable person would act given the circumstances but rather whether $B$ had a property right that $A$ interfered with. We could try to twist and distort the reasonable person test in a way to better capture Epstein's theoryso that the circumstances relevant to the reasonable person test are those that, if included, would capture cases where B's property right has been infringed - but simply by formulating the test this way, it is clear that it is

215. Richard A. Epstein, TAKings: Private Property AND the Power of EMinent DOMAIN 35-37 (1985).

216. Perry, supra note 199, at 451.

217. EPSTEIN, supra note 215, at 79 (1985). 
a bad fit. ${ }^{218}$ Better to abolish the reasonable person test altogether and replace it with something else-possibly by defining breach in negligence actions as "violations of another's property right."

At first blush, this seems to be in direct contradiction to this Article's larger thesis. The underlying theory of tort law is supposed to provide an answer about which circumstances are relevant to the reasonable person test. But if one adopts Epstein's theory, then not only does this tell us very little about what circumstances would be relevant, it suggests that we ought to get rid of the test altogether, at least in the realm of tort law. But this is not quite right. It is true that the underlying theory provides the circumstances relevant to the test. But depending on the field of law and its underlying theory, there may come a point where the reasonable person, malleable as she is, will be unable to capture what the law is supposed to be doing. The law does not employ the reasonable person test to determine whether a person committed premeditated murder or whether a state has violated the Equal Protection Clause. That is because the point of having a premeditated murder statute and an Equal Protection Clause is not captured by a reasonable person test. In those cases, the reasonable person has no business occupying that legal subject. Moran's Rethinking the Reasonable Person makes this claim when it suggests replacing the reasonable person test with a "culpable indifference" test for both criminal and civil negligence. ${ }^{219}$ The only difference is that by examining the underlying theory, we can better articulate why we think the test should be cordoned off.

The second reason for the weak connection between some corrective justice theories and the circumstances of the reasonable person test is the theory's incompleteness. Consider what Perry calls the fault-based volitionist view, which holds that it is A's voluntarily engaging in a wrongful act that gives rise to an obligation to compensate $B .{ }^{220}$ We cannot easily determine what circumstances are relevant to the reasonable person test, though at least we have an inkling that their inclusion should capture voluntary and wrongful conduct. But this is because the theory does not, yet, explain what wrongful and voluntary mean. Once the fault-based volitionist articulates a workable definition of those terms, we can determine

218. This is one reason to think that Epstein's account of tort law is revisionist and, in my opinion, not particularly persuasive.

219. See MoRAN, supra note 4, at 274.

220. See Perry, supra note 199, at 474-75. 
which circumstances would be relevant to the test. ${ }^{221}$ This can be generalized to other theories of corrective justice, including Jules Coleman's annulment thesis and the localized distributive justice theory. These theories will not necessarily help in filling out the features of the reasonable person. But this flows from the fact that most corrective justice theories are concerned with the mechanism by which rights and obligations arise in tort law. They are trying to explain how in some situations $A$ 's causal contribution to $B$ 's loss gives rise to a duty in $A$ to compensate $B$ and a corresponding right of recovery in $B$ from $A$. The explanation for that mechanism will not usually say much about how to fill in the concepts of fault and duty in tort law. ${ }^{222}$

\section{Miranda}

This Article has covered in general terms the way the reasonable person test functions in both criminal and tort law. My treatment of these subjects was fairly involved. This is due partly to the fact that both criminal and tort law have a long and storied history with the reasonable person test, but it is also because tort and criminal law are also closely connected to each other. They both speak in terms of fault and wrongdoing and, at least on some theories, have a strong connection to moral theory. They are similar enough that Mayo Moran treats negligence in criminal law and tort law roughly the same, advocating that we abolish the reasonable person test in both fields and replace it with a culpable indifference test that, she argues, works equally well in both fields. ${ }^{223}$ But the reasonable person is not just used to evaluate whether a defendant was at fault. She also peeks her head into areas that bear little resemblance to the recklessness, negligence, and self-defense claims this Article has discussed up to this point. This final subpart will more succinctly consider one of those areasthe Supreme Court's Miranda jurisprudence.

Anyone who studies the Supreme Court's Miranda decisions will be struck by the number of times that the reasonable person test comes into play. A police officer must give Miranda warnings whenever she interrogates a suspect who is in custody, and a suspect is "in custody" if

221. Or, alternatively, we could decide that the reasonable person test does not work in tort law, as Epstein would probably argue.

222. See Hershovitz, supra note 94, at 106 ("The corrective justice claim is that tort is an institution that, in the narrow view, enforces duties of repair, or in the broader view, works to put matters right between a wrongdoer and her victim. ... However, corrective justice theorists do not purport to provide a theory that explains the fine-grained features of tort doctrine, let alone one that should drive results in particular cases.").

223. See Moran, supra note 4, at 274. 
a reasonable person would not feel free to leave. ${ }^{224}$ An "interrogation" occurs when there are "any words or actions on the part of the police (other than those normally attendant to arrest and custody) that the police should know are reasonably likely to elicit an incriminating response from the suspect." 225 The warnings themselves must be given so that a reasonable person would understand them. ${ }^{226}$ However, no warning needs to be given if the questioning was "reasonably prompted by a concern for the public safety."227 In determining whether a suspect has asserted her Miranda rights, the Court asks whether a reasonable officer would consider the defendant's behavior or words as such an assertion. ${ }^{228}$ And after a suspect has asserted her right to remain silent, the police may resume the interrogation even if counsel is not present so long as a reasonable officer would think that the suspect initiated the exchange. ${ }^{229}$

The Court's treatment of the reasonable person test in its custodial interrogation cases has not been a model of clarity. It has, for example, frequently shifted its perspectives, inquiring at different times about the reasonable police officer, the reasonable suspect, and the reasonable member of society. ${ }^{230}$ Commentators have suggested that the Court's decisions reflect a particular type of reasonable defendant — one who "lacks basic human emotions, understandings, and expectations.",231 This ends up "mask[ing] the considerations that are actually driving [its] decisions." 232 Academics have also noted that Miranda jurisprudence has evolved significantly from the Supreme Court's initial decision in

224. Yarborough v. Alvarado, 541 U.S. 652, 663 (2004) (quoting Thompson v. Keohane, 516 U.S. 99, 112 (1995)).

225. Rhode Island v. Innis, 446 U.S. 291, 301 (1980) (footnote omitted). Although the Court applies a rather unusual reasonable person test: the definition of interrogation "focuses primarily upon the perceptions of the suspect, rather than the intent of the police." Id. As Mandiberg notes, the issue is "not how the suspect would view the officer's behavior, but how the reasonable officer should think the suspect would view it." Mandiberg, supra note 11 , at 1490 n. 43 .

226. See Florida v. Powell, 559 U.S. 50, 60 (2010).

227. New York v. Quarles, 467 U.S. 649, 656 (1984).

228. See Berghuis v. Thompkins, 130 S. Ct. 2250, 2259-60 (2010).

229. See Michigan v. Mosley, 423 U.S. 96, 104-05 (1975).

230. See Kinports, supra note 36.

231. Mandiberg, supra note 11, at 1482-83.

232. Id. at 1483. Mandiberg thinks that it is the interests in effective investigative procedures and in law and order that "usually prevail." Id. 
1966. ${ }^{233}$ Thus, a reference to "Miranda rights" might be intended to capture just the Warren Court's decision in that case, the body of case law that has developed since that decision, or the broader rules that govern police interrogation of suspects today. ${ }^{234}$

I do not want to get too bogged down in the specifics of the way the Court has articulated the various reasonable person tests, but instead I would like to concentrate on how the animating concerns of the Court's Miranda jurisprudence influence-or at least, should influence-the way the Court applies the test to a given case. On that note, this Article will cabin the discussion and assume that Miranda's protections are just what the Court says they are: prophylactic measures to protect against coerced confessions. $^{235}$ Miranda rights are "not themselves rights protected by the Constitution but are instead measures to insure that the right against compulsory self-incrimination is protected.,236

If the purpose of the Court's Miranda jurisprudence is to protect against coerced confessions, then the justification for the Miranda decision "rests on [a] cost-benefit analysis in which its costs in reducing the effectiveness of police interrogation are assayed against its benefits in protecting suspects from abuses."237 Unfortunately, as Cassell and Hayman recognize, there is very little data to go on: "In this 'empirical desert,' we have little knowledge about what police interrogation looked like shortly after Miranda, much less what it looks like today. How many suspects waive their Miranda rights? How many confess? How important are confessions to the outcome of prosecutions?"238 For purposes of this Article, however, we can cabin most of the empirical questions. I have limited my discussion to the question of which factors are relevant to the reasonable person inquiries that abound in Miranda, and thus, the causal effects of the inclusion or exclusion of these factors are all that need be considered. Moreover, because this Article has assumed that the purpose of Miranda is to guard against coerced confessions, we can limit the discussion even further: if the inclusion or exclusion of a given factor has

233. See Steven B. Duke, Does Miranda Protect the Innocent or the Guilty?, 10 CHAP. L. REv. 551, 553 (2007) ("Part of what fuels the vast literature about Miranda are the multitudinous meanings of the subject of the debate.").

234. Id. at 553-57.

235. See, e.g., J.D.B. v. North Carolina, 131 S. Ct. 2394, 2401 (2011) (“[T]his Court in Miranda adopted a set of prophylactic measures designed to safeguard the constitutional guarantee against self-incrimination.”).

236. New York v. Quarles, 467 U.S 649, 654 (1984) (quoting Michigan v. Tucker, 417 U.S. 433, 444 (1974)) (internal quotation marks omitted).

237. Paul G. Cassell \& Bret S. Hayman, Police Interrogation in the 1990s: An Empirical Study of the Effects of Miranda, 43 UCLA L. REV. 839, 841 (1996).

238. Id. at 840 (footnote omitted). 
no effect on the number of coerced confessions, we may discount it entirely. The question posed can therefore be answered via a three-part inquiry: First, we must ascertain which circumstances have a causal effect on coerced confessions. Second, we must determine what additional causal effects the inclusion or exclusion of each factor within that limited set has, broadly speaking. And third, we must consider the sum total of these effects and determine whether, taken together, they counsel in favor of or against including a particular factor in the reasonable person test.

With respect to the first prong, the question is whether the inclusion of a given factor would increase or decrease the number of confessions the police coerce out of suspects. ${ }^{239}$ We would not consider, as the Court did in its most recent decision on the subject, whether the exclusion of a factor "blind[s] [police officers or courts] to [a] commonsense reality",240 or whether a factor "would have affected how a reasonable person" would view the situation. ${ }^{241}$ We would instead have to first determine what constitutes a "coerced" confession. The line between cunning police practices and unconstitutional coercive pressure is not an easy one to draw. $^{242}$ Assuming we arrive at a satisfactory answer, the causal chain from the inclusion of a factor to its effect on the number of coerced confessions is complex. When a court is deciding whether a particular factor is relevant to Miranda, it is trying to determine whether the case fits into the broader rule ex post. The statement-whether coerced or not - has already been made to the police, and the question is whether to

239. It is possible that certain factors may causally affect the degree to which a confession is coerced. Perhaps, for example, the inclusion of the suspect's mental health history would not reduce the number of overall coerced confessions but may make some or all of those confessions less coercive. It is also an open question whether reducing the amount of coercion is a worthwhile objective.

240. J.D.B., 131 S. Ct. at 2399. This justification for the inclusion of age in the incustody question is a non sequitur: it just has nothing to do with any reason we might have for including a given factor.

241. Id. at 2402 (quoting Stansbury v. California, 511 U.S. 318, 325 (1994) (per curiam)) (internal quotation marks omitted). Similarly, no matter how one interprets the purposes of Miranda, the fact that the inclusion of a factor affects the reasonable person test will never be a good reason to include that factor.

242. This obviously is no small issue, but for some background on the major arguments, see Scott A. Anderson, The Enforcement Approach to Coercion, J. ETHICS \& Soc. PHIL., Oct. 2010, http://www.jesp.org/PDF/TheEnforcementApproachFinal.pdf. 
apply the exclusionary rule to it. ${ }^{243}$ The court, therefore, has to determine what effect the inclusion of the given factor will have on its-and other courts' - current and future determinations about whether the statement is excluded. It will then have to inquire about whether that effect will reduce the number of coerced statements made in the future. That part of the causal chain probably, but not necessarily, involves incentivizing the police, by threatening to exclude inculpatory statements, to take greater care in interrogating suspects: the assumption is that if the police take greater care, fewer coerced confessions will result.

Unfortunately, although a great deal has been written about the effect that Miranda has had on police interrogations generally, there are no studies I am aware of that seek to answer this more narrowly tailored question. The best approach is to attempt to extrapolate from the available data. There is some evidence suggesting Miranda warnings in general have very little effect: "About four out of five custodial suspects in the United States who are asked to submit to interrogation do so."244 But it is not clear whether there is any correlation between those who invoke their right to remain silent and those who received Miranda warnings. ${ }^{245}$ Moreover, it is difficult to determine how Miranda warnings affect confession rates because the latter are influenced by a wide variety of factors. ${ }^{246}$ And there are of course other possible causal chains. Miranda warnings, for example, may induce a suspect to speak: "Skillfully presented, the Miranda warnings themselves sound chords of fairness and sympathy at the outset of the interrogation. The interrogator ... becomes all the more persuasive by dint of his apparent candor and reasonableness." ${ }^{247}$ The inquiry is further complicated by the fact that even if the police comply with Miranda, the defendant may always challenge the admissibility of her statement on grounds that she was actually coerced. ${ }^{248}$ The decision to

243. See, e.g., Oregon v. Elstad, 470 U.S. 298, 306 (1985). The doctrine further complicates matters because, as the Elstad Court held, a coerced statement might still be used for impeachment purposes on cross-examination. Id. at 307.

244. Duke, supra note 233, at 555.

245. Id. at 557 ("Some seem to assume that whoever refuses to submit to interrogation after being warned of his rights does so because of the warning. But that is the post hoc, ergo propter hoc fallacy: temporal succession does not establish cause and effect."). Indeed, there is evidence that the correlation is much stronger between those who have been convicted of a felony in the past and those who invoke their Miranda rights. William J. Stuntz, Miranda’s Mistake, 99 Mich. L. REv. 975, 993 (2001) (citing Richard A. Leo, Inside the Interrogation Room, 86 J. CRIM. L. \& CRIMINOLOGY 266, 286-87 (1996)).

246. For a brief recap of some of these factors, see Duke, supra note 233, at 556 .

247. Patrick A. Malone, "You Have the Right To Remain Silent": Miranda After Twenty Years, 55 AM. SCHOLAR 367, 371 (1986).

248. Miranda v. Arizona, 384 U.S. 436, 475 (1966) (holding that even if the police give the proper warnings, the court must still determine whether the waiver was given voluntarily, knowingly, and intelligently). 
include a particular factor into the reasonable person test must therefore eliminate coerced confessions that courts would not otherwise exclude on grounds that they were in fact coerced. ${ }^{249}$ Finally, we do not know whether or to what extent the causal effects of these factors interrelate. It might be, for example, that factor $x$ has, on its own, no causal effect whatsoever but that coupled with the introduction of factor $y$, it does. The complexity of the causal chain makes me skeptical that Miranda has much of an effect on the number of coerced confessions. ${ }^{250}$ In any case, as this brief discussion demonstrates, the first prong of the inquiry is extraordinarily difficult and perhaps impossible to definitively answer.

With respect to the second prong, the inquiry becomes even more complicated. To reach an answer, we must take those factors that do have an effect on the number of coerced confessions the police extract and determine what additional effects those factors have, broadly speaking. We must, in other words, decide what negative side effects courts should be willing to live with in their quest to reduce coerced statements. If the goal were solely to reduce coercive interrogation practices, we could throw out the reasonable person test and declare that the police cannot talk to anyone. But we reject that out of hand because the costs associated with that rule are too high: the police have a legitimate interest in investigating crime, and it would unduly hamper their efforts if they were not permitted to speak to anyone. ${ }^{251}$ Thus, we recognize that there are countervailing considerations at play that must be considered. Answering this question is thus more complicated than the first prong of the inquiry for two reasons. First, it requires us to determine as a normative matter which causal effects are properly considered in assessing whether a factor should be included in a reasonable person test. There are a great many effects that a factor might have, but only some of them ought to be taken into account. A factor's impact on the ability of the police to ferret out guilty parties is certainly an important concern; that same factor's tendency

249. But see Welsh S. White, Miranda's Failure To Restrain Pernicious Interrogation Practices, 99 Mich. L. REV. 1211, 1220 (2001) (suggesting that judges are highly unlikely to find that a confession was involuntary if the police complied with Miranda's procedural protections).

250. See Jackson, supra note 1, at 13-14.

251. Cassell and Fowles suggest that Miranda warnings do increase the number of suspects to exercise their right to remain silent and that this results in a lower rate of convicting the guilty. See Paul G. Cassell \& Richard Fowles, Handcuffing the Cops? A Thirty Year Perspective on Miranda's Harmful Effects on Law Enforcement, 50 STAN. L. REV. 1055, 1126-27 (1998). 
to, say, cause police to wear black socks instead of blue ones is probably not.

Second, rather than cabining our inquiry into one particular causal effect-in prong one, whether a factor increased or decreased the number of coerced confessions-we must consider a wide range of causal effects. Mapping out the various ways in which the inclusion of a given factor affected the number of coerced confessions was difficult enough, but in prong two, we must make the same empirical inquires into a host of different effects. To give only a couple of examples to demonstrate how unmanageable this project is, consider some rather far-fetched but possible examples. Perhaps the innocent are better protected by the inclusion of a given factor because it increases the number of guilty suspects who exercise their right to remain silent. If the guilty exercised this right less frequently, they would lie more often and their lies would make the police much more skeptical of the innocents who truthfully deny their guilt. ${ }^{252}$ Similarly, it might be the case that if the police are unable to obtain confessions from the guilty as the result of the inclusion of a given factor, they may extract a larger number of false confessions from the innocent. ${ }^{253}$

Finally, with respect to the third prong, we must make a value judgment about whether the sum total of causal effects associated with a factor or set of factors justifies its inclusion. Again, I do not want to fall too far down the rabbit hole, but there is quite a bit of room for disagreement about the extent to which providing protection against coerced confessions outweighs $^{254}$ the deleterious side effects that might result. I hesitate to go any further if only because, as the discussion above has shown, we cannot even know which effects we must weigh without answering the first two prongs of the inquiry.

All this is to say that the question of which factors are relevant to Miranda's various reasonable person tests is not easily answered. Still, there are certain conclusions to be drawn. The factors relevant to Miranda's reasonable person test will be dictated in large part by one's underlying normative commitments. Any complete answer will have to provide a working definition of coercion, determine which causal effects are proper

252. See Daniel J. Seidmann \& Alex Stein, The Right to Silence Helps the Innocent: A Game-Theoretic Analysis of the Fifth Amendment Privilege, 114 HARV. L. REV. 430, $433-45$ (2000).

253. Paul G. Cassell, Protecting the Innocent from False Confessions and Lost Confessions — and from Miranda, 88 J. CRIM. L. \& CRIMINOLOGY 497, 498-99 (1998).

254. Though this Article uses the term outweighs, it is not to suggest that a strict cost-benefit analysis is the only way to make this determination. A hard-line deontologist could say that coerced confessions are always wrong and must be minimized regardless of any other effects that might come into play. The term outweighs is capacious enough to cover these kinds of alternative decisionmaking methods. 
concerns of Miranda, and provide a criterion to weigh those causal effects against each other. Although there are a number of knotty empirical questions that must also be answered, we will not get anywhere without grappling with and providing a satisfactory answer to these value-laden questions.

\section{CONCLUSION}

In this Article, I have demonstrated that in the context of the reasonable person test, the traditional way of distinguishing relevant characteristics from irrelevant ones-appealing to the distinction between objective and subjective facts-must be rejected. There is no principled way to sort these characteristics a priori. Rather, the factors we consider relevant to the test will vary depending not just on the field of law but also on the underlying theory that animates that field of law. In discussing the test's use in the criminal law, tort law, and Miranda jurisprudence, I have provided an explanation into the way this theory works in practice, describing the mechanisms by which underlying theories sort relevant characteristics from irrelevant ones. I have shown that the various debates scholars have over the proper way to apply the reasonable person test will not and cannot be resolved without first examining our underlying commitments. It is of course theoretically possible that there is significant consistency across these theories - that, for example, the factors a corrective justice approach to tort law deems relevant turn out to be precisely the same ones that a tort economic theorist or a blame-based criminal law theorist would include-but that would be completely fortuitous and I imagine, unlikely. This Article has demonstrated that there is no single, all-encompassing reasonable person test, as scholars commonly assume. In reality, there are a variety of reasonable person tests, each of which uses a different set of factors. Which test is used will depend both on the area of law and also normative judgments that lurk just below the surface of courts' and scholars' discussions on how the reasonable person test applies.

A couple of parting thoughts. This work has been from start to finish dedicated to the theory of the reasonable person test. But there is more to understanding the proper application of an area of law to a given case than examining the underlying theory. Moran's book is a prime example, where she takes empirical facts about the way the reasonable person test is used to discriminate on the basis of race, sex, mental disability, and age and argues from there that the test itself ought to be abandoned. These practical or empirical concerns will always be relevant to the debate, and 
I do not mean to suggest they are unimportant. But theory, too, has an important role to play, and this Article provides a sound methodology to approach that issue.

Along the same lines, in arguing that there is significant variation in the way the reasonable person test works, I remain open to the possibility that there still exists a common core of circumstances that will be relevant across the board. This feeds back into the point made above that we may decide that the reasonable person has no business being used in a given subject. ${ }^{255}$ There may well come a point where we realize, as a result of our theoretical commitments, that the reasonable person test just should not be used in, say, negligence or Miranda jurisprudence. But the fact that we are able to make this claim presupposes that there are common attributes among the various iterations of the test. These features might all be in the test's form, but some of them might also be certain circumstances that will always be relevant. My hunch is that this is exactly what is going on and that the reasonable person's circumstances must include the physical facts known to the defendant, for example, the physical layout of the nearby space and the shape and size of nearby objects, and the defendant's mental characteristics associated with perception, for example, blindness and language ability, but that is a question for another article. As I mentioned in the introduction, I knew that I would not be able to develop a complete theory of the reasonable person in one shot. But I hope that this Article is the necessary first step toward that larger project - a project that, as I have argued, will also force us to grapple with our most basic normative commitments.

255. See supra pp. 698-700. 